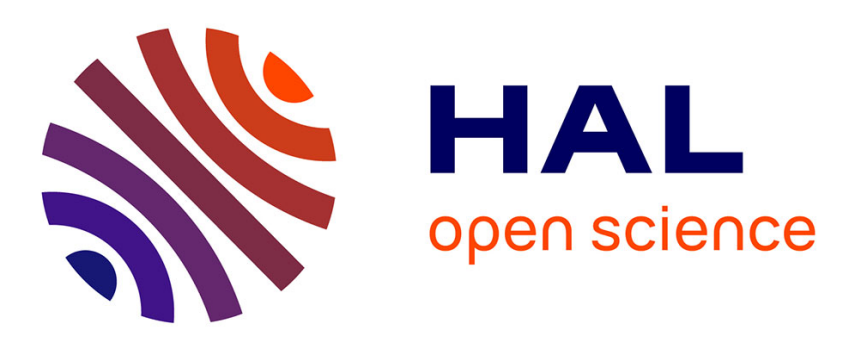

\title{
Spatial history: railways, uneven development and population change in France and Great Britain, 1850-1914
}

\author{
Robert Schwartz, Ian Gregory, Thomas Thévenin
}

\section{To cite this version:}

Robert Schwartz, Ian Gregory, Thomas Thévenin. Spatial history: railways, uneven development and population change in France and Great Britain, 1850-1914. Journal of Interdisciplinary History, 2011, 42 (1), pp.53-88. 10.1162/JINH_a_00205 . hal-00731645

\section{HAL Id: hal-00731645 \\ https://hal.science/hal-00731645}

Submitted on 22 Jul 2019

HAL is a multi-disciplinary open access archive for the deposit and dissemination of scientific research documents, whether they are published or not. The documents may come from teaching and research institutions in France or abroad, or from public or private research centers.
L'archive ouverte pluridisciplinaire HAL, est destinée au dépôt et à la diffusion de documents scientifiques de niveau recherche, publiés ou non, émanant des établissements d'enseignement et de recherche français ou étrangers, des laboratoires publics ou privés. 


\section{Robert Schwartz, Ian Gregory, and Thomas Thévenin}

\section{Spatial History: Railways, Uneven Development, and Population Change in France and Great Britain, I850-I9I4}

Robert Schwartz is E. Nevius Rodman Professor of History, Mount Holyoke College. He is the author of "Rail Transport, Agrarian Crisis, and the Restructuring of Agriculture: France and Great Britain Confront Globalization, I860-1900," Social Science History, XXXIV (2010), 229-255; "New Tools for Clio: GIS, Railways, and Change over Time and Space in France and Great Britain, I840-I9I4," digital publication (2007), at http://digitalhistory.unl.edu// essays/schwartzessay.php.

Ian Gregory is Senior Lecturer in Digital Humanities, Lancaster University. He is the author of, with Paul S. Ell, Historical GIS: Technologies, Methodologies and Scholarship (New York, 2007); with David Cooper, "Mapping the English Lake District: A Literary GIS," Transactions of the Institute of British Geographers, XXXVI (201 I), 89-108.

Thomas Thévenin is Assistant Professor of Geography, University of Burgundy, and researcher, ThéMA. He is the author of, with Schwartz and Gregory, "Railways and Agriculture in France and Great Britain, I850 to I9I4," in Alistair Geddes and Gregory (eds.), ReThinking Space and Place: New Directions in Historical GIS (Bloomington, 201 I); with Arnaud Banos, "Generation of Potential Fields and Route Simulation Based on the Household Travel Survey," in Marius Theriault and François Des Rosiers (eds.), Modeling Urban Dynamics (London, 20IO).

This article is based on research supported by a Collaborative Research Grant from the National Endowment for the Humanities (RA-50577-060). The authors thank Meritxell Gallart, Mateu Morillas, and J. Martí-Domínguez for their support in producing the GIs data on British railways from Michael H. Cobb, The Railways of Great Britain: An Historical Atlas (Shepperton, 2006; orig. pub. 2003). This article is part of a European Science Foundation initiative (Eurocores) and the project within it, "Water, Road and Rail: The Development of European Waterways, Road and Rail Infrastructures: A Geographical Information System for the History of European Integration (I825-2005), "directed by Jordi Martí Henneberg, Inventing Europe grant FP-005. Mathilde Pizzuto and Loïc Sapet helped to construct the GIS data on the French rail system with funds from the NEH Grant and with grant funds from the French National Agency of Research (ANR o7 Corp or9), respectively. Much of the data for Britain were taken from the Great Britain Historical GIS (GBHGIS, http://www.gbhgis.org). Schwartz would also like to thank Melissa Joyce for help in preparing the GIS data; François Caron for helpful comments on an early version of the essay; Humphrey Southall for supplying data on the Agricultural Returns for England and Wales; William G. Skinner for allowing use of his GIS data on French population within cantonal boundaries; and the family of Denitsa Tilkidjiev, who was tragically killed in an automobile accident, in memory of her indispensable work as a research assistant while a student at Mount Holyoke College. Gregory acknowledges the support of the Leverhulme Trust under Early Career Fellowship ECF/4O I I 5 , which enabled him to prepare the net migration data. Marietta Clement's keen eyes eliminated stylistic infelicities and errors, and Robert Herbert brought Lachembeaudie's poem to Schwartz's attention (Schwartz's translation).

(C) 201 I by the Massachusetts Institute of Technology and The Journal of Interdisciplinary History, Inc. 
Thus, in hamlets deprived of

The abundant, civilizing waters running all around them,

Does poverty, ignorance, and envy reign.

The iron arteries of the beneficent network

Over every piece of soil affected and crossed,

Carry life through the social body.

Every city is becoming a vast reservoir

From which come great flows of wealth and knowledge.

Pierre Lachembeaudie, "La Vapeur"

A poem hailing the civilizing effects of railways was but one of myriad expressions celebrating the benefits of the railway age. Such enthusiasm-quaint perhaps to modern ears - takes us back to the heroic phase of steam locomotion and iron roads, to the marvel of steam and speed. The better to appreciate that era, historians need to revisit not only the archives but also the territory of historical geography. For French historians, this directive means returning to the methods of Bloch and Braudel, which combined history and geography in comparative perspective. The call to "return" is apt: while social scientists are pursuing questions of spatiality, historians continue to move in other directions. Consequently, geographical aspects of the past have all but disappeared from the historian's agenda, as a review of articles in leading historical journals clearly shows. Although allusions to "space" and "sites" are common today, these terms are typically either metaphors or indefinite locations for the study of cultural practice. Over the past decade, neither "geography" nor "spatial" have appeared in The American Historical Review's topical indexes. As Lewis recently put it, "Few historians pay explicit attention to geography, and few geographers give more than a token nod to history. Yet some of us would stubbornly concur . . . that historical processes can only be understood as they take place geographically, and that geographical patterns can only be explained through historical analysis." Meanwhile, on the other side of the disciplinary divide, Jones laments the lack of historical depth in human geography, which in turn reifies postmodern claims concerning the historically disconnected and self-referential present. To "bridge the divide," writes Baker, a historical geographer, we need to "deepen the historical awareness of geographers and to widen the 
geographical consciousness of historians." The time for spatial history has certainly come. ${ }^{1}$

This article comparing the effects of railways on rural society in Britain and France seeks to demonstrate the blending of historical research with geographical thinking and new methods of spatial analysis, drawing on the digital technology of geographical information systems (GIS) and spatial statistical analysis. In contrast to studies of railway policy and economic change that focus on the nation as a whole, we examine national patterns in relation to regional and local differences, the better to describe uneven economic, demographic, and cultural change across time and geographical space. On the national scale, we identify broad contours of uneven geographical development and population change, the

I In the context of French history, "the spatial turn" underway in the social sciences could be called "a spatial re-turn" to the blending of geography and history prominent in the early Annales school-integrating the practice of Vidal de la Bache and Marc Bloch, or Roger Dion and Fernand Braudel - and to treating questions of historical change and regional variation as Bloch did in Les Caractères originaux de l'histoire rurale française (Paris, I988; orig. pub. I93 I). As for comparative history, see Bloch, "A Contribution towards a Comparative History of European Societies" [1937], in idem, Land and Work in Medieval Europe (New York, I967), 44-8I; idem, Les Caractères originaux de l'histoire rurale française (Paris, I93 I); William H. Sewell, "Marc Bloch and the Logic of Comparative History," History and Theory, VI (1967), 208-2I8.

For the spatial turn in social science, see Michael Goodchild et al., "Towards Spatially Integrated Social Science," International Regional Science Review, XXIII (2000), I39-I 59; in sociology, Andrew Abbott, "Of Time and Space: The Contemporary Relevance of the Chicago School," Social Forces, LXXV (I997), I I49-I I82; Ann R. Tickamyer, "Space Matters! Spatial Inequality in Future Sociology," Contemporary Sociology, XXIX (2000), 805-8I4; Susan W. Friedman, "Historical Geography and Historical Sociology: Our Honest Toil and the Spatial Turn," in Gerard Delanty and Engin F. Isin (eds.), Handbook of Historical Sociology (London, 2003), I08-I3 I; Javier Auyero, "Spaces and Places as Sites and Objects of Politics," in Robert Goodin and Charles Tilly (eds.), Oxford Handbook of Contextual Political Studies (New York, forthcoming).

With three or four notable exceptions, articles published since I980 show a remarkable lack of geographical analysis or even geographical interest. An internet search on "geography" and "space" produces a mere handful of articles in academic journals, as well as a special issue of the Journal of Interdisciplinary History - XXXII (2002), 5I 5-704 " The Productivity of Urban Space in Northern Europe")—about space in medieval and early modern Europe. However, all of these articles discuss "space" in the sense of a cultural site or undifferentiated "public space." For "space" as metaphor or indefinite location, see Sewell, "Space in Contentious Politics," in Ronald Aminzade et al. (eds.), Silence and Voice in the Study of Contentious Politics (Cambridge, Mass., 200I), 5I-88. Martin Lewis, review of Susan Schulten, The Geographical Imagination in America, 1880-1950 (Chicago, 200I), American Historical Review, CVII (2004), at http://www.historycooperative.org/journals/ahr/I07.I/br_8I.html (September 20, 2004); Rhys Jones, "What Time Human Geography?" Progress in Human Geography, XXVIII (2004), 296; Alan R. H. Baker, History and Geography: Bridging the Divide (New York, 2003): xii. 
role of railways in restructuring rural economies, and shifts in regional economic inequalities. Developments on an international scale also enter the analysis; the decline in transport costs and the productivity of American agriculture intensified competition, generating an intense phase of globalization in foodstuffs and the consequent agrarian crisis that struck British and French farmers during the last quarter of the nineteenth century (c. I876 to I896). Finally, whereas previous studies tend to concentrate on one or another aspect of the story-be it railways, demography, agriculture, or economic development - the aim in this article is to bring these aspects together and illuminate the interconnections among them.

At the regional and local scale, we question the commonly held view that the coincidence of railway expansion into the countryside and increasing rural out-migration is evidence that railways accelerated rural depopulation and hastened the decline of rural communities. This article offers a different interpretation, one that a few scholars have mentioned, but none have pursued. Rather than hollowing out the village economy, the transformative effects of railway transportation arguably gave rural communities a second chance at stability or limited growth and opened new cultural horizons. Accessible rail transport stimulated commerce and created new economic opportunities for the marketing of agricultural production and for finding employment in retail commerce, extractive industries, and logging (for railway timbers and ties), or in such service trades as the horse-drawn carriage of goods to and from railway stations. Consequently, rural communities with ready access to rail service might have enjoyed an economic revitalization, at least temporarily, that slowed the pace of rural depopulation. Moreover, when the agrarian depression struck in the later I870s, I 880 os, and I890s, the economic benefits of rail service likely diminished rural out-migration in communities where rail transport was close at hand. ${ }^{2}$

Impermanent as revitalization was, its cultural effects would

2 By and large, the view about the coincidence about rural railway expansion and outmigration is based more on assertion than on systematic analysis of local communities and spatial variations over time. In this respect, it mimics the perspective of economic historians who focus on the national aggregate - the effects of railways on economic growth, modernization, and agriculture overall — with little or no attention to the temporal geography of regional and local variations. François Caron, Histoire des chemins de fer en France, Tome premier (1740-1883) (Paris, 1997), 577-578. 
endure because rural inhabitants realized that new economic opportunities and employment possibilities made literacy and schooling more advantageous than before. In addition, the increased circulation of newspapers and mail made rural inhabitants aware of events and jobs beyond the sound of the village bell. Indeed, however modest was the impact of railways on the performance of the economy or the agrarian sector as a whole, their effects on rural communities and farmers appear highly significant when studied not in the aggregate but in terms of varied spatial patterns of uneven geographical development that shifted over time. ${ }^{3}$

UNEVEN DEVELOPMENT The incidence of rural decline and rural revitalization are components of what social scientists term uneven development. Geographer Neil Smith equated this unevenness with the shifting geography of modern capitalism, a process through which "space" is produced through economic change. He refers to "space" not as a fixed and neutral container for human activities but as nexus of natural resources and sites of production that are integrated into the capitalist system. These "spaces" are continually in flux-developing, declining, expanding, and contracting in step with the amount of capital investment and level of production in a specific territory at a given time. ${ }^{4}$

Another helpful perspective can be found in the work of Massey, who broadened the determinist approach to spatial politi-

3 Considerable debate arose in response to Robert Fogel's argument that the contribution of railroads to economic growth in the United States was a good deal more modest than generally thought. Scholars have tested his claim in different European countries with varying results. A point of agreement in the field is that in densely settled regions, such as the American East and Western Europe, rail transport stimulated commercial expansion and tended to reinforce existing urban economic hierarchies. See Fogel, Railroads and American Economic Growth: Essays in Econometric History (Baltimore, 1964); Albert Fishlow, American Railroads and the Transformation of the Ante-bellum Economy (Cambridge, Mass., I965); G. R. Hawke, Railways and Economic Growth in England and Wales, 1840-1870 (New York, 1970); Patrick Karl O'Brien, Railways and the Economic Development of Western Europe, 1830-1914 (New York, I983); Roger Price, The Modernization of Rural France: Communications Networks and Agricultural Market Structures in Nineteenth-Century France (New York,I983); Richard White, "It's Your Misfortune and None of MY Own": A History of the American West (Norman, I99I); Caron, Histoire des chemins de fer. Jeremy Atack et al., "Did Railroads Induce or Follow Economic Growth? Urbanization and Population Growth in the American Midwest, I850-I860," Social Science History, XXXIV (20I0), I $7 \mathrm{I}-\mathrm{I} 97$, recently re-opened the debate by using GIS, confirming Fishlow's general argument about the Midwest with much-improved geohistorical data.

4 Neil Smith, Uneven Development: Nature, Capital, and the Production of Space (New York, I984). 
cal economy developed by Lefebvre, Harvey, and Smith. In her classic study of Britain in the late twentieth century, Spatial Divisions of Labour: Social Structures and the Geography of Production, as well as in subsequent articles and in her most recent book, For Space, Massey defines geography as the study of social relations stretched across space and through time. Incorporating culture, gender, race, and open historicity in her recent studies, she argues that "places" are not static but active and historically conditioned localities. Formed by layers of past investment and the spatial division of labor that such investment produced, places-whether industrial, agrarian, or administrative in historical charactercontinue to shape and constrain their own diverse paths of development. These structural determinants, however, need not be decisive. Political actions can intervene to modify historically conditioned spatial relations. Space and place have contingent trajectories, always undergoing material reconstruction and cultural representation. ${ }^{5}$

THE BIG PICTURE: NATIONAL PATTERNS OF RAILWAY EXPANSION Uneven economic development in nineteenth-century Europe, France, and Britain leaps out from maps of the era showing the expansion of the steam-powered railway system. As fixed capital of unparalleled cost and as construction projects of unprecedented size and complexity, railway systems propeled a second phase of industrialization and transformed social and physical landscapes. Railways altered economic relations and cultural environments, often determining the livelihoods of urban and rural inhabitants. Railway scheduling even changed the perception of time, breaking it down to minutes and seconds; a minute late was enough to miss a train. Space, too, changed as high-speed rail transport

5 Henri Lefebvre, The Production of Space (Cambridge, Mass., I99I; orig. pub. I974); David Harvey, Social Justice and the City (London, I973); idem, Justice, Nature and the Geography of Difference (Cambridge, Mass., I996); Smith, Uneven Development; Doreen B. Massey, Spatial Divisions of Labor, Social Structures, and the Geography of Production (New York, I995; orig. pub. I984). Massey's later work assigns additional causal potential to human agency at the expense of the historically embedded structural determinants that she emphasized in her earlier work: Space, Place, and Gender (Minneapolis, I994); idem, "Power-geometries and the Politics of Space-Time": Hettner-Lecture 1998 (Heidelberg, I999); idem, "Talking of Space-Time," Transactions of the Institute of British Geographers, XXVI (200I), 257-26I; idem and John Allen (eds.), Uneven Re-development: Cities and Regions in Transition: A Reader (London, I988); idem, For Space (London, 2005). 
shrank geographical space, connected remote areas to a central network, and altered rural and urban landscapes through the construction of rail lines and stations and the intensification of market forces. So far as speed was concerned, in the early nineteenth century, horse-drawn coaches were thought remarkable to reach Edinburgh from London in sixty-nine hours. By the I880s, the same trip took only ten hours by train. ${ }^{6}$

The Growth of Railway Systems over Time The timing and pace of railway expansion followed different but converging paths in Britain and France, according to the ways by which their differing political economies modernized. In Britain, the early, explosive growth of the rail system during the I 840 os and early I 850 s was followed by a second round of brisk expansion during the I860s and a more gradual pace of growth afterward. In France, steady advance in railway construction was the rule. Turning upward in the mid-I84Os, the pace of expansion picked up and sustained itself from the I 850 os to the early I 880 os, with a noticeable break during the Franco-Prussian War (I870-I87I). Thereafter, growth subsided during the industrial and agrarian contractions of the I 880 os and earlyi 890 s. By the end of the century, the two rail systems were converging both in terms of the length of their main lines in operation and the density of railways per population (see Figure I). By then, the French tortoise appeared to be closing on the British hare. ${ }^{7}$

The Growth of Rail Networks over Time and Space The growth of the rail system in England and Wales bore witness to the conquest of space by private enterprise during the industrial era. True, Parliamentary authority was needed to permit companies to construct lines, and, at times, rail-company proposals that appeared to be inadequately planned and financed failed to win approval. Parliament also rejected schemes that met with determined resistance, such as the plan to extend a line in the scenic Lake District that preservationists opposed in I 887. Parliament also exercised regula-

6 Derek Aldcroft, "The Railway Age," Refresh, XII (I99I), I-8. A pioneering work on the cultural changes associated with the railway age is Wolfgang Schivelbusch, The Railway Journey: the Industrialization of Time and Space in the 19th Century (Berkeley, I986).

7 Schwartz, "Rail Transport, Agrarian Crisis, and the Restructuring of Agriculture: France and Great Britain Confront Globalization, I860-I900," Social Science History, III (2010), 229257. 
Fig. 1 Kilometers of Railways per Ioo,ooo People in France and in England and Wales

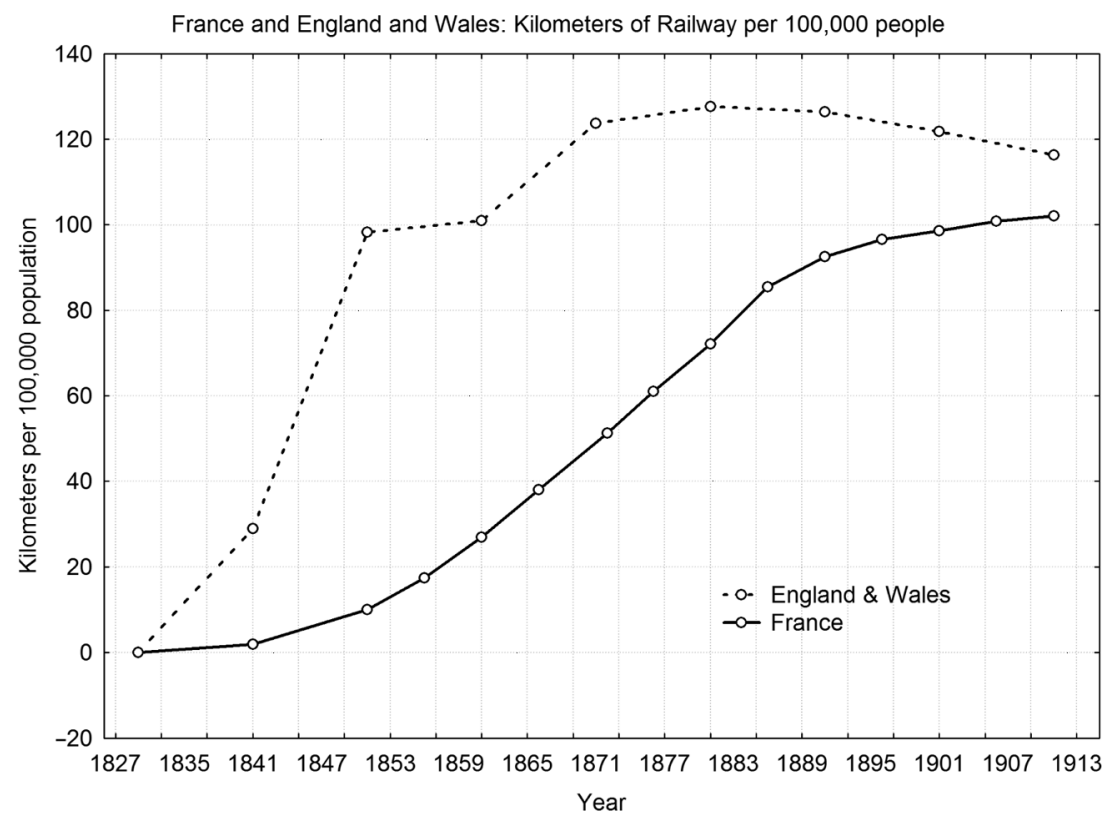

SOURCES Association of American Railroads and Bureau of Railway Economics, Comparative Railway Statistics of the United States, the United Kingdom, France and Germany for 1900 and 1909 (Washington, D.C., I9II); Jack Simmons, The Railway in England and Wales, 1830-1914 (Leicester, I978), Appendix 2, 276-277; Ministère des Travaux Public, Direction des Chemins de Fer et des Routes, Statistique centrale des chemins de ferres français au 31 décembre 1932: France, voies ferrées d'intérêt local, tramways, services subventionnés d'automobiles (Paris, I935), 5; Roget Price, The Modernization of Rural France (London, 1983), 25.

tory authority over all lines, tightening it in the I870s. Nevertheless, all of the British railways were constructed and owned by privately owned joint-stock companies. Since their first and foremost interest was profit, the securing of money-making routes was of utmost importance. ${ }^{8}$

8 Ambleside Railway hearings, March I5-2I, I887, House of Commons Evidence, I887, I, House of Lords Library, London. For good accounts of the roles of Parliament and the British state with regard to railways, see Frederick S. Williams, Our Iron Roads: Their History, Construction and Administration (London, I968; orig. pub. I884); Jack Simmons, The Railway in England and Wales, 1830-1914. I. The System and Its Working (Leicester, I978), 6I-I I2, I66I78. The profit motivation of privately held railways in Britain is also treated in Frank Dobbin, Forging Industrial Policy: The United States, Britain, and France in the Railway Age (New York, 1994). 
The competitive search for profitable routes is captured by a series of maps showing the growing extent of the rail network from I 844 to I9I4 (see Figure 2). The geography of the system in I 850 shows an emerging network that linked major cities (including London), ports (Liverpool and Bristol), areas rich in coal and iron (Newcastle and Cardiff), and such manufacturing centers as Manchester, Birmingham, Sheffield, and Leeds. Links between London and East Anglia, England's preeminent agricultural region, foreshadowed the next phase of expansion during the I $860 \mathrm{os}$ and early I870s, which reached increasingly into hitherto neglected rural areas. A company's development of rural branchesmany, if not most, of them deemed unprofitable-was an effort to capture additional traffic for lucrative trunk lines and to limit or prevent rival companies from making inroads on their territorial domains. In that respect, Casson concludes, the British system was over-built and inefficient. ${ }^{9}$

For small communities, however, branch lines that brought rail service nearby were most welcome. A remote town newly endowed with a station was well poised to become a thriving market center in which farmers would find growing opportunities to sell their produce and to which village job seekers would likely turn first to find work. By I 876, England and Wales had approximately 4 , I9O rail stations in operation, and relatively few of the 630 registration districts lacked a rail connection of some sort (see Figure 2). In parishes, the cells making up the districts, those endowed with rail stations early in the process of expansion, typically saw their populations increase. ${ }^{10}$

Another feature introduced in the second round of expansion during the I860s was the successful conquest of rugged terrain. Thanks to the increasing power of locomotives, the replacement of iron rails by steel, improved coupling and braking systems, and other technological improvements, rail companies were able to push farther into the countryside and over hills and mountains into remote areas, opening new lines that incorporated additional re-

9 Mark Casson, The World's First Railway System: Enterprise, Competition, and Regulation on the Railway Network in Victorian Britain (New York, 2009).

Io Michael H. Cobb, Railways of Great Britain: A Historical Atlas (Shepperton, 2006; orig. pub. 2003); Gregory and Jordi Martí-Henneberg, “The Railways, Urbanization and Local Geography in England and Wales, I825-I9I I," Social Science History, XXXIV (2010), I99228 . 
Fig. 2 The Growth of Railways in England and Wales, I850-I920

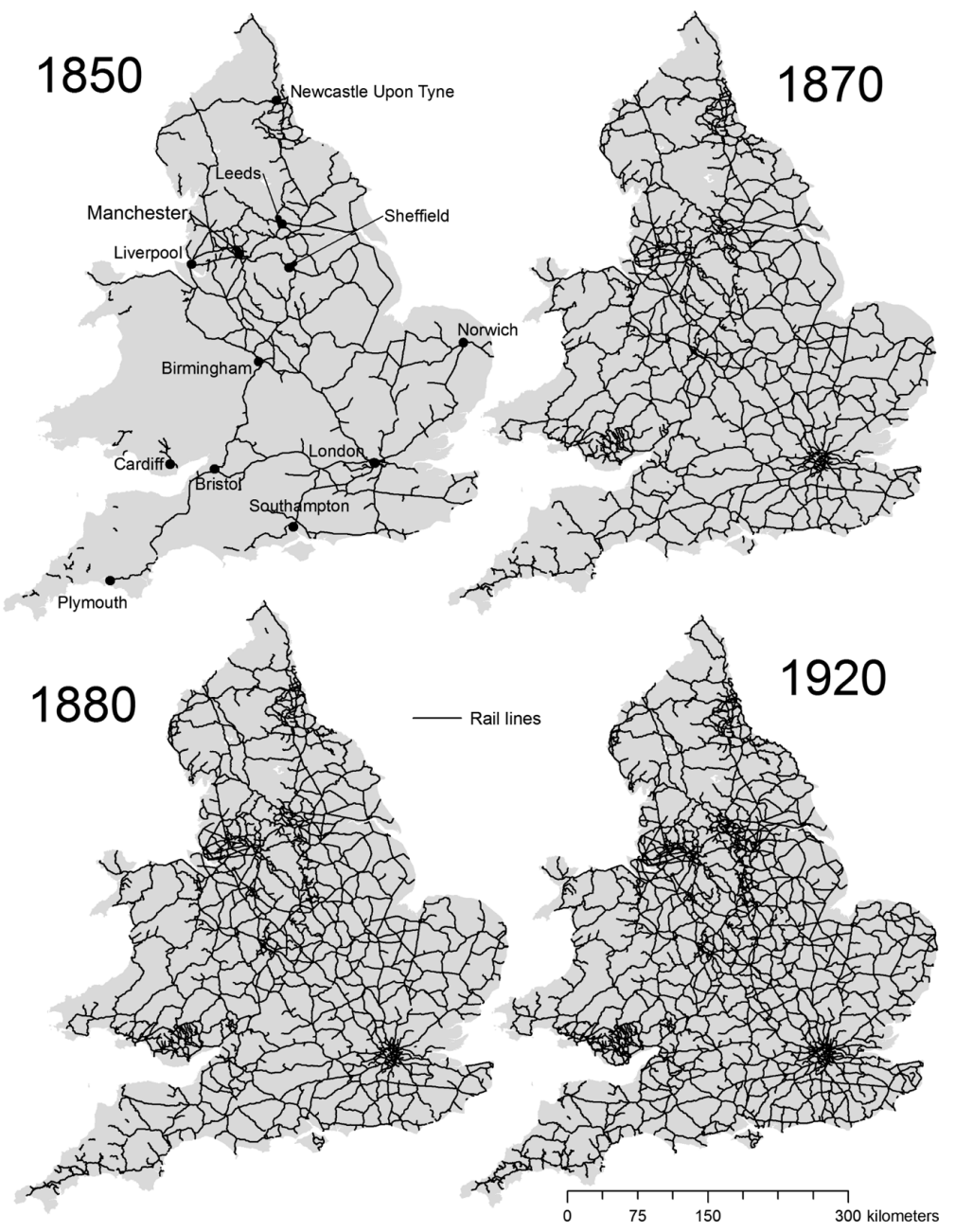

SOURCE Great Britain Railway GIs, based on Michael H. Cobb, Railways of Great Britain: A Historical Atlas at the Scale of 1 Inch to 1 Mile (Shepperton, 2006; orig. pub. 2003).

sources and populations into both the national rail networks and national markets (see Figure 3). Prominent in this respect were the upland regions in the northwest, comprising the Lake District and mining areas near the border with Scotland. In the southwest, new lines negotiated steeper terrain in Devon and Cornwall. Even more striking developments were underway in Wales. The rug- 
Fig. 3 Mean Slopes of Terrain Crossed by Rail Lines in England and Wales, I830-I855 and I856-I876 (Expressed as the Average Percentage Change over a Rail Segment)

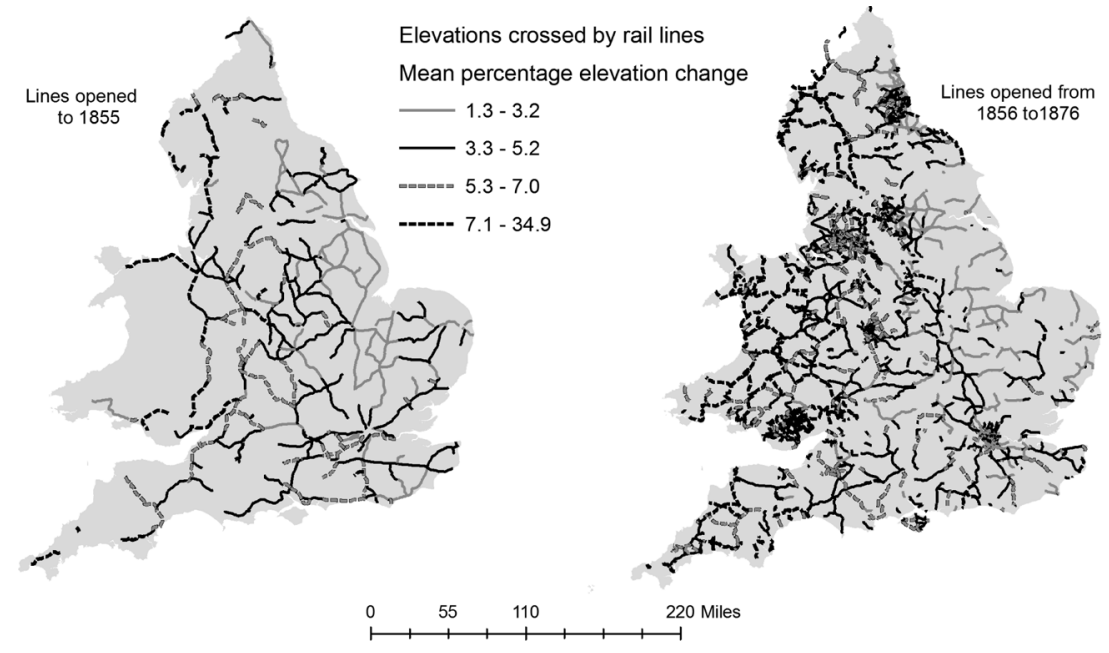

SOURCES Digital terrain model constructed by Schwartz from the Shuttle Radar Mission images, distributed by the United States Geological Survey; Great Britain Railway GIS.

ged, interior terrain of Wales was all but untouched by rail until the I 850 , but thereafter a major program of railway construction was devoted to conquering its hills and mountains. Not surprisingly, the slate mines in northern Wales and the great coal mines in the southern valleys near Cardiff were the first areas to be well served by rail transport. To a lesser degree, the agrarian regions of Central Wales were drawn into the expanding rail network as well, beginning in the I 860 s.

FRANCE A comparison of France with Britain brings out the particularities of a rail system forged by a mixture of state tutelage and private enterprise, government and private financing. From I 828 to I 84I, the first few railways in France stemmed from local initiatives with minimal involvement of the central government. From I 842 onward, however, the French state largely shaped the national system. State engineers of the Ponts et Chaussées (department of bridges and highways) designed a national network that imitated the improved highway system of the eighteenth and early 
nineteenth centuries. At the outset, all of the rail lines conceded to private companies led to Paris, forming a radial network connecting the capital with major ports and economically important regions. Only in the I 870 s did lateral lines with east-west linkages begin to appear (see Figure 4$){ }^{11}$

As first stipulated in the Law of I I June I 842, the financing of rail construction was to be a joint affair, shared by the state and private companies. In I 859, the French state started to encourage investment in private rail companies by guaranteeing an attractive rate of return, virtually eliminating risk for investors holding stock in lines authorized by the government. At the end of the I 870 , after its defeat by Prussia in I87I and the bloody repression of the Paris Commune in the same year, the liberal Third Republic committed itself to an enormous expansion of railways as a vital step toward modernizing its large but stagnating rural economy. In I 878, Charles Freycinet, the minister of public works, initiated a program of expansion for both the main system and a newer, secondary network consisting of "lines of local interest," a long-term project that began to show results during the late I880s and I 890 os. ${ }^{12}$

By I9I4, the primary system had grown by about $8,000 \mathrm{~km}$ since the Freycinet program began, reaching a total of $40,875 \mathrm{~km}$ on the eve of the war. Meanwhile, the secondary network gradually came into operation. After a slow start during the I880s and I 890 s, it grew rapidly from I900 to World War I, after which it peaked at 20,29I km in I928. From the outset, local lines were expected to run continual deficits that would have to be covered by subsidies from the state and localities. Indeed, the political calculus behind this expansion is worth emphasizing. The government, prompted by pressure from regional and local interests where rail service was scant or nonexistent, likely recognized that the main network then in service had aggravated disparities among various regions of France, favoring the north and northeast especially over the Midi (south). Implementing the Freycinet program, including

I I A common railway function was the carriage of coal or other raw materials to manufacturing sites, the first example being the line transporting coal from mines at Andrézieux to metalworking firms in Saint Étienne. François and Maguy Palau, Le rail en France: Les 80 premières lignes, 1828-1851 (Paris, I995), I8, 20-2I.

I2 Price, Modernization, 208-2I I; Caron, Histoire des chemins de fer, 58, 539-540. This paragraph draws from Schwartz,"Rail Transport and the Agrarian Crisis," 236-237, 239. 
FRANCE AND GREAT BRITAIN, I850-I9I4 | $\mathbf{6 5}$

Fig. 4 The Growth of the French Rail System, I850-1920

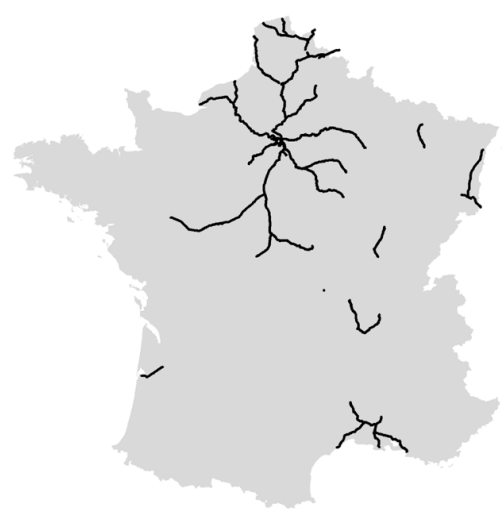

1850

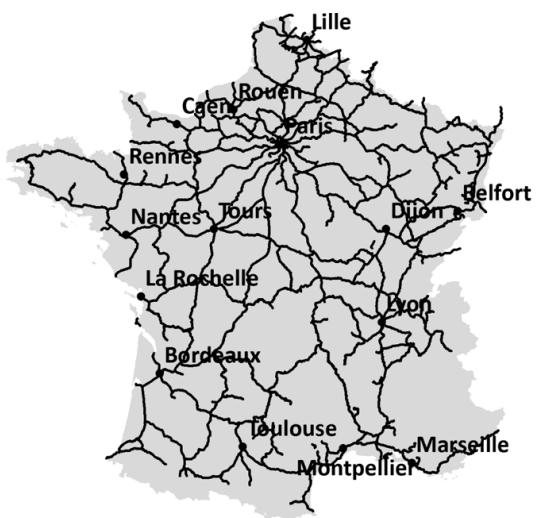

1870

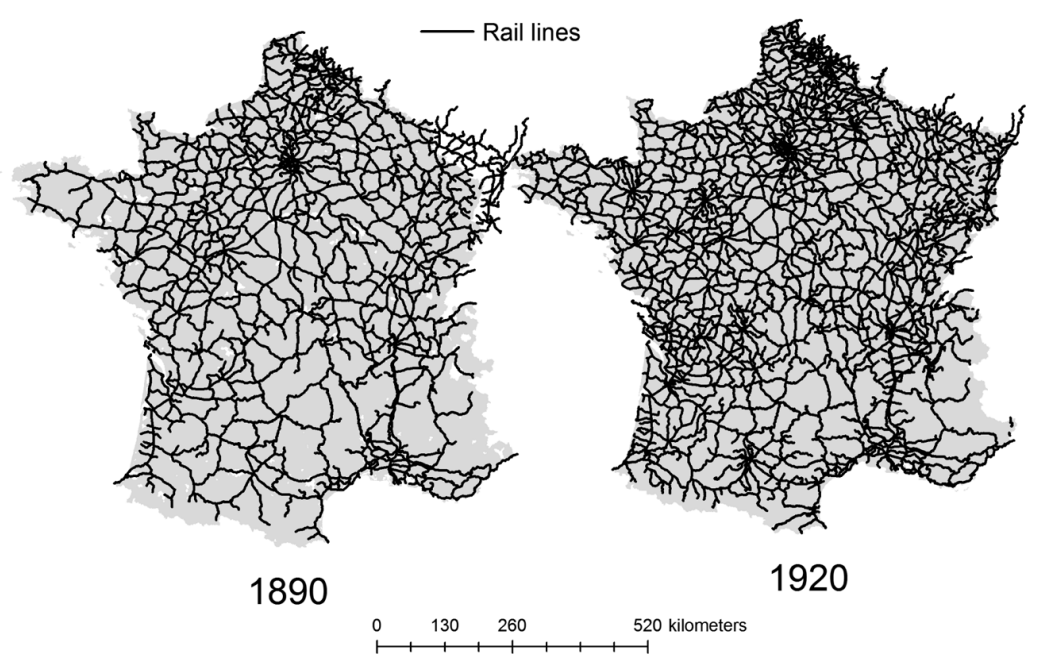

SOURCE France Railway GIS, rail lines digitized from Carte des chemins de fer française: SNCF, 1944, Département des Cartes et Plans, Ge BB 368, Bibliothèque National de France, Paris.

the secondary network of small branch lines, was thus an act of political will from above and below. In the democratizing Third Republic, no region was to be left behind. By I920, much of that pledge had been fulfilled. ${ }^{13}$

In I 890,80 to 90 percent of the French rail system was in place. The disparities of rail service and economic benefits were I 3 Price, Modernization, 2 I8-2 I9; Ministère des Travaux Public, Direction des Chemins de 
Fig. 5 Geographical Clustering of Rail Transport in France during the I 890 s

(French territory after 1871)

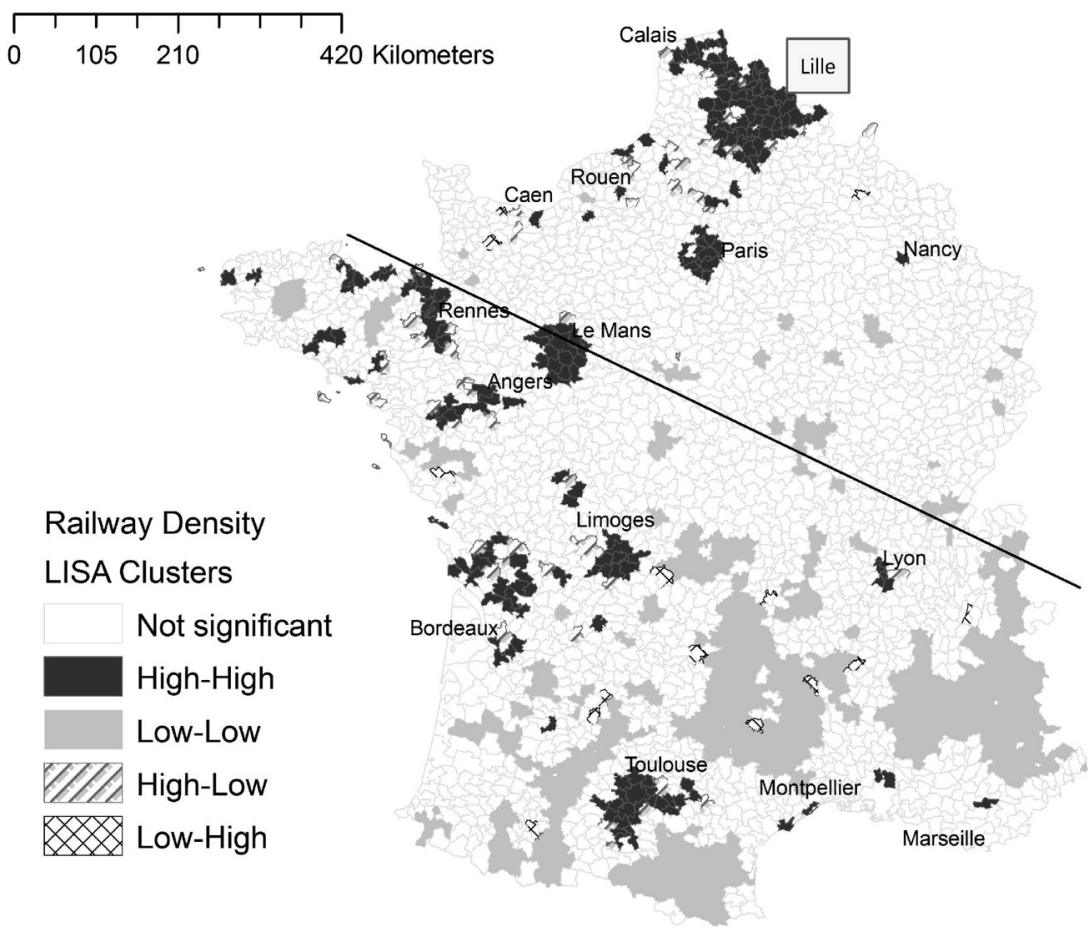

SOURCES France Railway GIS; population figures from the French census of I89I, published in the Bulletin des Lois de la République Française, No. I474 (Paris, I892), 884-924.

being reduced, a process that would culminate in the I920s. The disparities remaining during the I 890 os stand out when a geostatistical technique is used to identify clusters of two kinds-cantons that enjoyed little or no proximate access to rail service, as indicated by rail-line density, and those with uncommonly high levels of service. Figure 5 shows that underserved areas (in solid gray)

Fer et des Routes, Statistique centrale des chemins de ferres français au 31 décembre 1932: France, voies ferrées d'intérêt local, tramways, services subventionnés d'automobiles (Paris, I935), 5. Remy Guyot, "Rails et voies des chemins de fer secondaires," Revue d'Historie des chemins de fer, 24-25 (2OOI), I 42-I 43, presents different figures for the secondary network, showing a decline in $\mathrm{km}$ use after I9I 8 . 
were predominant south of a line running from Saint Mâlo to Geneva, the line commonly used to demarcate the developed north from the less developed south. ${ }^{14}$

Favored regions (in black) stand out, too. Bordeaux Toulouse, Montpellier, Marseille, and Lyon in the Midi were exceptionally well served by rail as hubs for the transport of mass-market wines and perishable fruits and vegetables to large urban markets in Paris and the north. The concentrations of railways around $\mathrm{Li}-$ moges, Angers, Le Mans, and Rennes provided regions of expanding livestock farming with efficient transport to meet the growing demand for meat and fresh milk in the capital and other large cities. Aside from the Paris region, the largest geographical cluster of rail service, not surprisingly, was located in the agglomeration of industry and highly productive agriculture centered on the cities of Lille and Calais.

While some regions were "left behind" because they lost out in the fierce competition for rail transport, other regions in the disadvantaged south were victims of challenging topography and an associated history of poor communications and sparse capital investment. The effect of these disadvantages is reflected in Figure 6 , which shows the rail lines existing in 1890 overlaid on a digital terrain model. Before the I860s, when such technological improvements as steel rails, more powerful locomotives, and effective coupling systems took hold, the hilly and mountainous regions of the Massif Central, Pyrenees, and Alps were deemed all but inaccessible to steam-powered locomotion. In the southern Alps, things began to change in I875 with the opening of a line from Marseille to Gap. In the northwest, Brittany saw its first rail service to the cities of Rennes and Nantes in the late I 850 ; lines along the perimeters of the peninsula opened in the 1860 s and to some parts of the interior during the I870s and I880s. In the Indre, the Black Valley immortalized in George Sand's rustic novels en-

I4 The map displays clusters of spatially autocorrelated levels of rail density across I,950 cantons of France in I890. Mapping the spatial statistic called Local Index of Spatial Autocorrelation (LISA) highlights regional disparities between contiguous areas where rail service was uncommonly dense (shaded gray) and those where it was virtually nonexistent (areas in black). The geography of disadvantage corresponds somewhat with the geography of sharecropping that was prevalent in parts of the west and southwest. See Jonathan Liebowitz, "Tenants, Sharecroppers, and the French Agricultural Depression of the Late Nineteenth Century," Journal of Interdisciplinary History, XIX (1989), 432-434. 
Fig. 6 The French Rail System in I890 and the Challenge of Topography

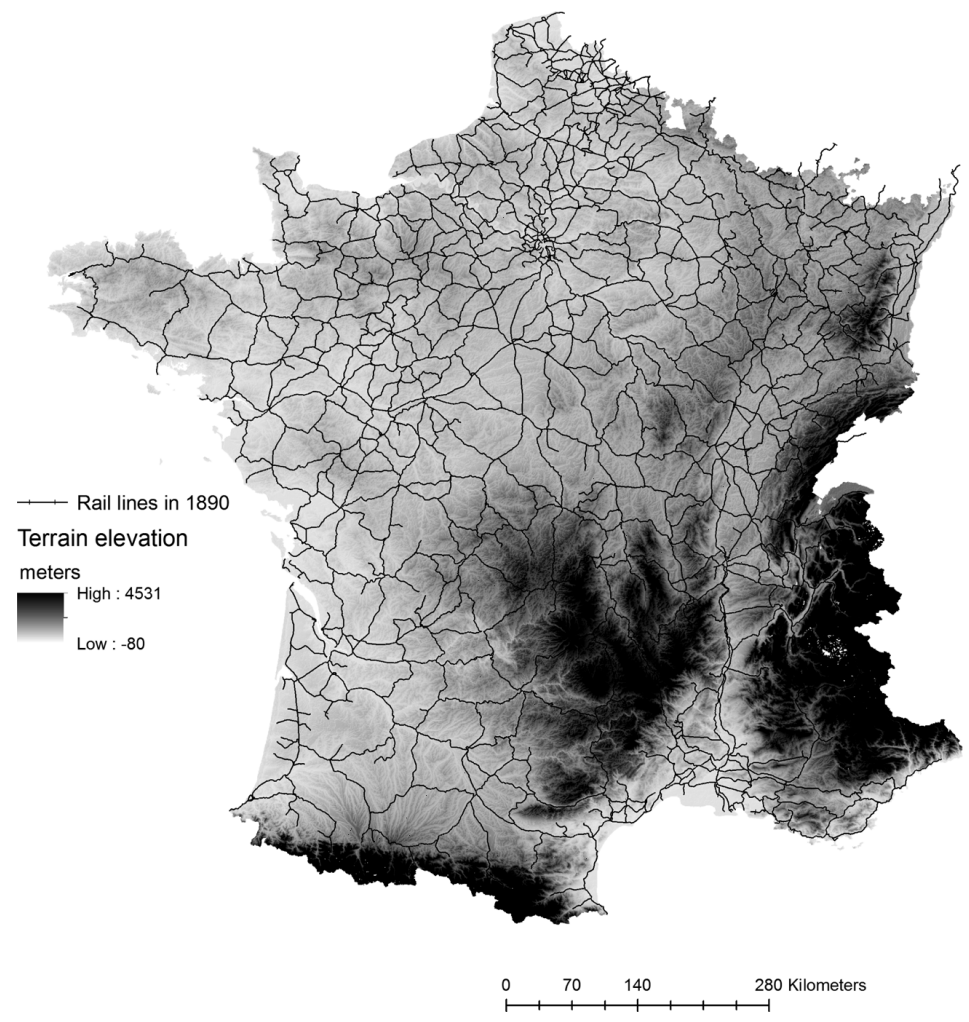

SOURCE Digital terrain model constructed by Schwartz from the Shuttle Radar Mission images, distributed by the United States Geological Survey.

tered the railway age in I 882 when a branch line running from Châteauroux to La Châtre opened. Hence, in I 890, clusters of upland cantons in the south and in the Alps still lagged well behind the developing northeast, west, and southwest in the transport revolution. These disparities in railway development were what the Freycinet program was intended to reduce (see Figure 7 ). ${ }^{15}$

I5 Bernard Cima, Histoire Chonologique des Chemins de Fer Français (Menton, n.d.), in his CD-ROM atlas provides an extremely useful year-by-year chronology of the openings (and closings) of main lines and stations, the length of lines so affected, and accompanying maps from I 827 to 2000. Despite the opening of lines in Brittany during the I860s and I870s, Caron, Histoire des chemins de fer, 554-555, suggests that reliable service in many parts of the peninsula was well established only in the I 88 os. In the interesting debate about the extent to 
Fig. 7 Increase in Rail Accessibility in France, I860s-I890s

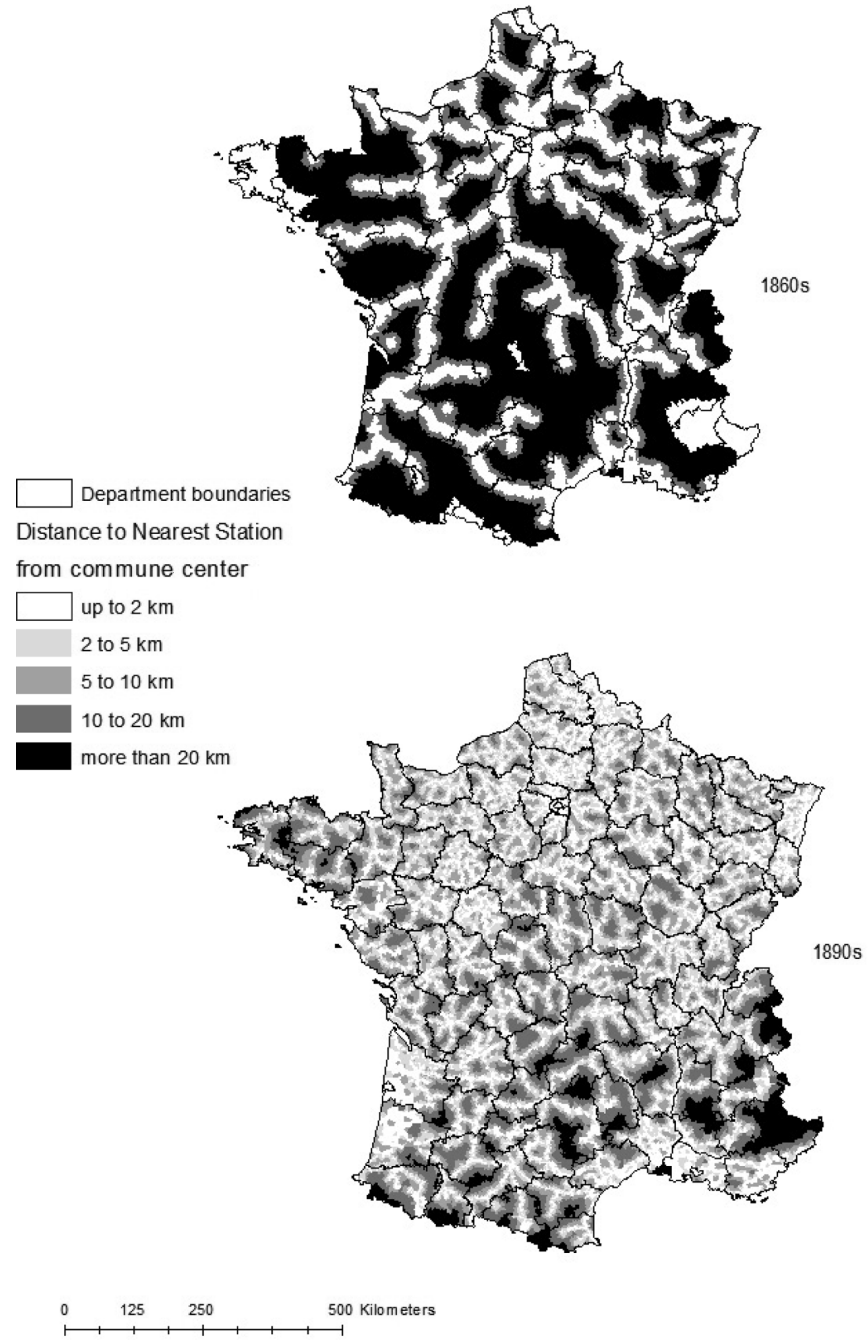

SOURCE France Railway GIS, rail lines digitized from Carte des chemins de fer française: SNCF, 1944, Département des Cartes et Plans, Ge BB 368, Bibliothèque National de France, Paris.

which diversities were altered or modified, the sharpest differences are between Price and Caron. Price, Modernization, 6, concludes that railways, even after the Freycinet plan came into being, diminished rural isolation but aggravated pre-existing economic inequalities among rural regions. Caron, Histoire des chemins de fer, 572, argues that the old disparities between the rich northeast and the poor south were attenuated and that some of the poorest regions caught up. Our work lends support to Caron's argument. 
RAILWAYS AND RURAL ECONOMIC CHANGE The arrival and growth of rail service in the countryside and remote districts reinforced or diminished economic disparities among regions and localities. In well-served areas, rail transport tended to stimulate commerce, extractive industries, and agriculture, depending upon their mix of endowments. In regions where service was remote or nonexistent, inertia and decline were apt to worsen, characterized by rising rates of out-migration and depopulation, as in the Lodève region of Languedoc. There, de-industrialization, in conjunction with the rise of viticulture and the attendant risks of monoculture - and the phylloxera epidemic in particularcomprised but one of many variants in the shifting spatial political economy associated with railway expansion. ${ }^{16}$

Changing patterns of uneven development in regions and localities were conditioned by circumstances other than the accessibility of rail transport; prevailing market conditions were usually predominant. In agriculture, the transport revolution increased competition at the international level, especially in wheat. The consequences of globalizing markets in foodstuffs flowed downward through markets at the national and regional levels to arrive at the farm gate. Beginning in the I870s, the arrival in European markets of vast quantities of cheaper wheat from the United States saw prices tumble in Britain, France, and Germany. With farm costs remaining stable or rising, and with a series of poor harvests striking British and French cereal farmers, agriculture fell into a long depression from c. I876 to I 896. British and French farmers struggled through a first crisis of globalization; those who survived began to breathe easier only at the turn of the century. In this sense, what railways - and steamships - gave with one hand they often took away years later with the other, forcing even favored communities to adapt to changing market conditions. ${ }^{17}$

I6 The flourishing textile center of Lodève, already facing decline in the I850s, placed its hopes for revival on the Company of the Midi's plan to establish a new route linking Montpellier to Paris, making Lodève a hub for traffic going north and south. When the Ministry of Public Works rejected the plan in I862, the city's industrial future was foreclosed. Christopher H. Johnson, The Life and Death of Industrial Languedoc, 1700-1920 (New York, I995), I76-I96.

I7 Schwartz, "Rail Transport and the Agrarian Crisis," 234-236. The "Great Agricultural Depression" portrayed by Rowland E. Prothero (Lord Ernle) in English Farming Past and Present (London, I9I2) no longer seems as generalized and stark in the light of later research, beginning with T. W. Fletcher, "The Great Depression in English Agriculture I873-96," Economic History Review, XIII (I96I), 4I7-432, which moderated the depth of the depression 
In Britain, the shifts toward concentration and specialization in extractive industries and agriculture began in the I860s. Rail transport that reached into remote areas opened a variety of new economic opportunities. Coal and other natural resources in previously inaccessible areas - the stone quarries of Leicestershire, the slate quarries of northern Wales, and the lead mines of Shropshire and Central Wales, for example-were now brought into production. In the eastern Midlands, railways revitalized the mining of iron ore and led to the establishment of smaller centers of iron production in rural Northampton as the larger and older sites in Staffordshire and Derbyshire faced the exhaustion of local ores. ${ }^{18}$

In agrarian regions, railways revitalized local agriculture by opening distant markets and stimulating local production. By the I 870 s, thanks to the speed and lowered cost of rail transport, the trade in perishable food was rapidly expanding into more distant regions to meet the rising demand in growing cities. Fresh vegetables, such as peas from Essex and strawberries from Hampshire, found their way to London tables, as did meat from as far away as Scotland. Railways benefited stock raising by making improved animal feed readily available, and it benefited farming by bringing fertilizing night soil from large cities to farms beyond the range of horse-drawn carting and, somewhat later, artificial fertilizers from ports and factories. In addition, railways fostered livestock and dairy production, viable alternatives to grain production when the fall in grain prices of the I 870 s ended Western Europe's golden age of wheat farming and inaugurated a prolonged agrarian depression (see Figure 8).

After the depression worsened in the I880s, a modest recovery took hold in the I89os. In wheat farming - the sector most

and differentiated declining crop production from stable or rising stock raising. More recent research suggests, for example, that the incomes of landlords and farmers suffered more than that of laborers, while recognizing the need to explore regional variability in farmers' responses to declining cereal prices. See Michael Turner, "Agricultural Output, Income and Productivity," in E. J. T. Collins (ed.), The Agrarian History of England and Wales. VII. 18501914 (Cambridge, 2000), Part I, 224-320; Bethanie Afton, "The Great Agricultural Depression in the English Chalklands: The Hampshire Experience," Agricultural History Review, XLIV (1996), I9I-205, for a regional study showing one variant of farmer response to declining cereal prices- a shift to grain production for animal feed instead of human consumption. I8 The following two paragraphs draw from Schwartz, "Railways and Rural Development in England and Wales, I850-I9I4," in Christian Sorrel (ed.), Frontières, contacts, échanges: Hommages à André Palluel (Chambéry, 2002), 24I-259. David Turnock, An Historical Geography of Railways in Great Britain and Ireland (Brookfield, Vt., I998), 254-255, 272-273, 280-28I. 
Fig. 8 Regional Specialization, the Decline of Wheat Production, and the Expansion of Livestock Farming in England and Wales I 869-I93 I
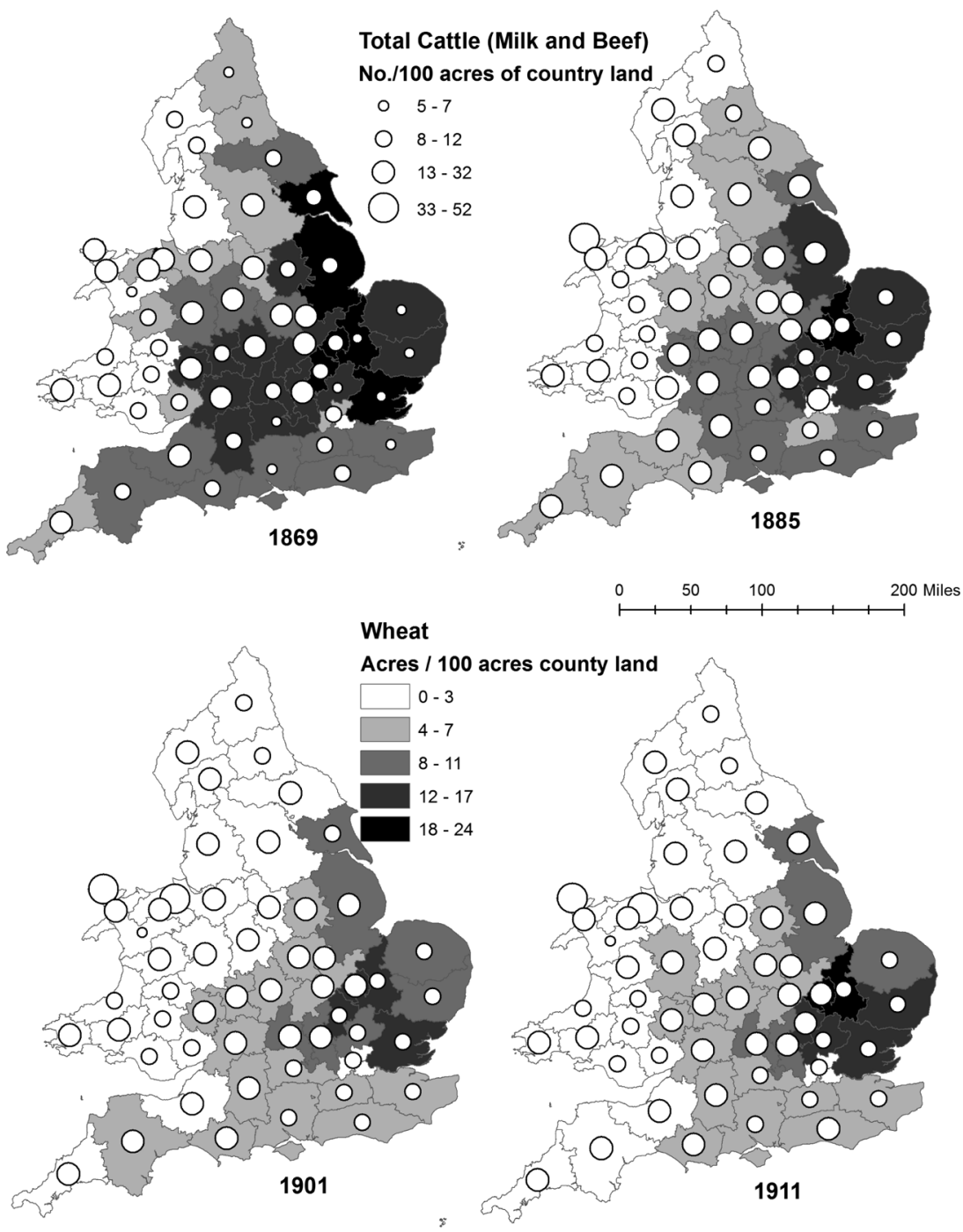

SOURCE Agricultural Returns for Great Britain for the years I869, I885, I90I, I9Io, British Parliamentary Papers. 
affected-recovery was slow and prolonged during the late I 890 s and the first years of the twentieth century, the result of a substantial reduction in domestic wheat cultivation and slightly higher prices. Meanwhile, some farmers successfully adapted to the new market conditions through stock raising and the fresh-meat trade, both of which continued to grow; others shifted to dairy farming in response to the rising urban demand for butter and especially fresh milk (see Figure 9). By the late I870s, more than a decade before modern refrigeration came into general use, fresh milk from as far as Dorset, Wiltshire, and Somerset helped to supply the booming London market, a trade further augmented in the I $880 \mathrm{os}$ and I 890 os by the increasing number of dairy farms in the West Country (Dorset, Devon, and Gloucestershire) and in western Wales. Similarly, in the north, railways enabled Yorkshire farmers to sell their milk in Leeds, Newcastle, and Liverpool. ${ }^{19}$

RURAL PATTERNS OF CHANGE IN FRANCE In agriculture at midcentury, family farming committed to polyculture remained typical in most of France, and the production of cereal crops-wheat increasingly predominant over rye and other lesser grains-was considered the base of agrarian production in the majority of regions. The production of cereals favored an increase in large farming units that, unlike family farms, utilized hired labor and entailed substantial capital. In the second half of the century, however, family or peasant farming expanded, and large farming declined as the growth of stock raising outpaced the growth of cereals in response to a rising demand for meat and dairy products and declining prices for wheat. More intense in some regions than in others, this general transformation entailed a major change in land use: By I929, 66 percent of agricultural land was devoted to pasture and animal husbandry and 34 percent to wheat and other crops-the reverse of the proportions in I 862 and much more extensive than the shift from arable to grassland in England and Wales. Meanwhile, and more significantly, the pronounced gap in 1840 be-

I9 Collins, "Rural and Agricultural Change," in idem (ed.), Agrarian History, VII, Part I, I 38-I40, I46-I49, I 58-I67; Turner, "Agricultural Output, Income and Productivity,” ibid., 295-305; Turnock, Railways in Great Britain, 254-255; Philip S. Bagwell, "The Decline of Rural Isolation," in G. E. Mingay (ed.), Rural Life in Victorian England (London, I977), I, 3637; Richard Perren, “The Marketing of Agricultural Products: Farm Gate to Retail Store," in Collins (ed.), Agrarian History, VII, II, 973-974. 
Fig. 9 Railways and Rural Developments in England and Wales, c. I 880

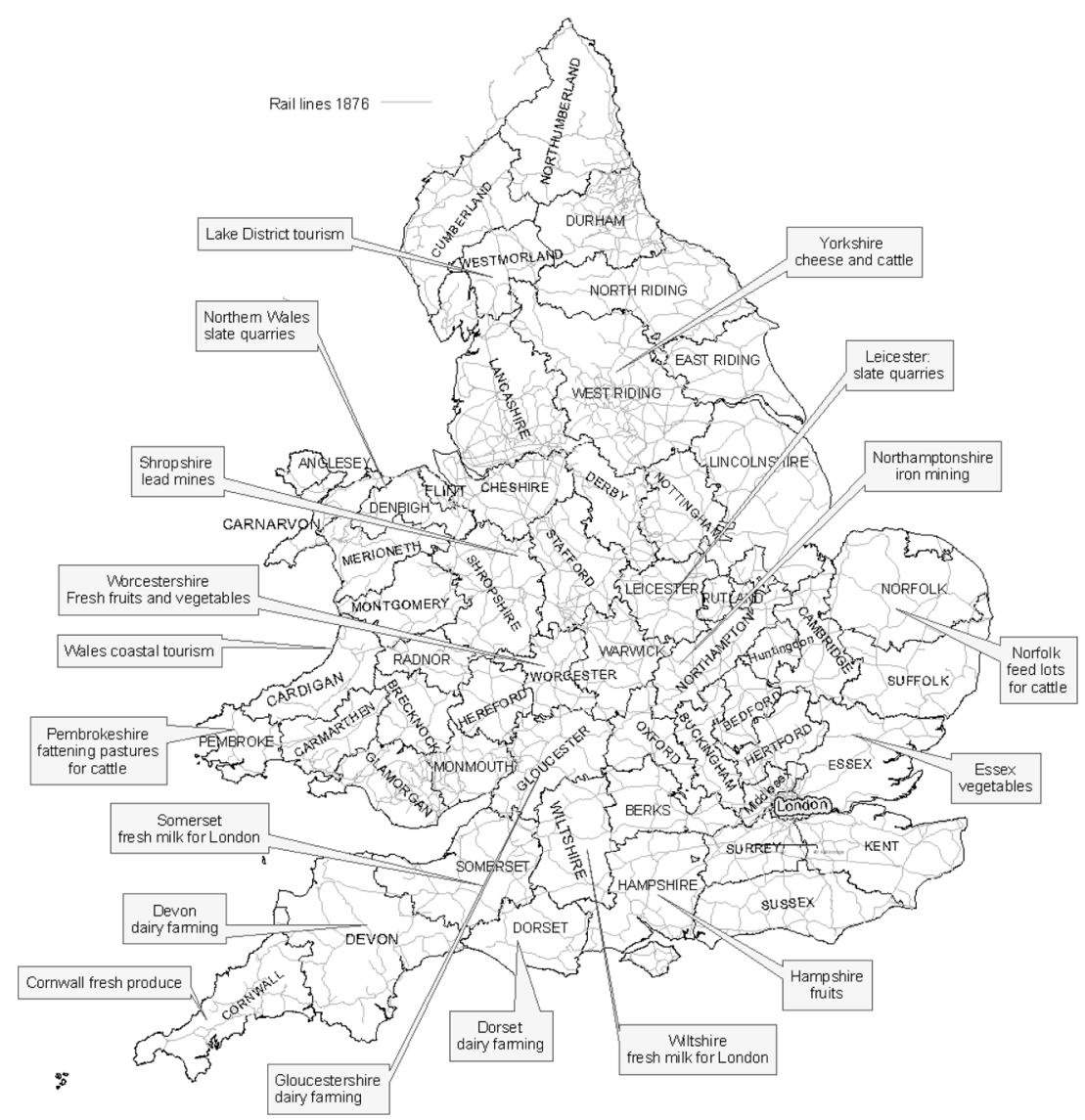

SOURCE Great Britain Railway GIS; Jack Simmons, The Railway in Town and Country, 18301914 (Newton Abbot, I986), 229-335; David Turnock, An Historical Geography of Railways in Great Britain and Ireland (Brookfield, Vt., I998), 254-255, 272-273, 280-28I.

tween the rich north and the poor south had diminished. Indeed, by I900, the growing productivity of southern agriculture surpassed the northern rate, bringing about a convergence in yields and total agrarian output per worker. ${ }^{20}$

In this convergence, expanding rail transport facilitated the

20 For the strengthening of family farming and the persistence of polyculture, see Paul Hohenberg, "Change in Rural France in the Period of Industrialization, I 830-I9I4," Journal of Economic History, XXXII (1972), 219-240. For figures on regional variations in agrarian pro- 
further development of regional specialization geared to provisioning distant urban markets. The vegetable and fruit gardens established in Marseilles and Peripignan before the I 840 os greatly expanded after the arrival of railways. In I86I, for example, the Paris-Lyon-Mediterranean Rail Company opened a successful high-speed express service to transport fresh produce from the Midi to Paris. In plateaus of the southeast, rail transport prompted the creation of entirely new farming areas to produce perishable fruits and vegetables. In regions of the north, west, center, and central east, dairy farming and the fresh-meat trade flourished. Areas bringing fresh milk and meat to Paris, for example, extended into Lower Normandy, the Loire Atlantique, the Limousin, the Nièvre, the Allier, and even further afield, thanks to the increasing speed and diminished cost of rail transport. In the late i860s, François Jacquim wrote of the astonishing growth in Paris markets, where unprecedented quantities of wine, metallurgical products, and live animals were arriving by train. The statistical service of the French government captured the geography of increasing regional specialization in a map showing the density of cows by department in relation to the national average in I 882. In regions of the west and the center of France, a notable expansion and intensification had occurred since the advent of rail transport. ${ }^{21}$

As with cattle, so with wine. The arrival of rail transport stimulated a remarkable rise in the production of wine in distant regions. Production in the Beaujolais, for instance, redoubled after rail transport arrived in I 855 . Even more striking was the vast increase in the old province of Langeudoc. Astonished, Jacquim de-

duction and the onset of regional specialization in animal production and in fruits and vegetables, see J. C. Toutain, "La croissance inégales des regions françaises: l'agriculture de I8IoI990," Revue historique, DXC (I994), 3 I 5-359 (334-340, for evidence that productivity in the north and south of France converged). George W. Grantham, "Scale and Organization in French Farming, I 840-I880," in William N. Parker and Eric L. Jones (eds.), European Peasants and Their Markets: Essays in Agrarian Economic History (Princeton, I975), 293-326. In England and Wales, the percentage of agricultural land under plow was $57 \%$ in I $875,4 \mathrm{I} \%$ in I9I 4 . Calculations derive from Collins, "Conclusion," in idem (ed.), Agrarian History, VII, Part II, 2 I 42 (Table I).

$2 \mathrm{I}$ Caron, Histoire des chemins de fer, 56I-563, 535; Hugh D. Clout, The Land of France, 18151914 (Boston, I983), 7I, 80-8I, I04-I05, I37; idem, Agriculture in France on the Eve of the Railway Age (Totowa, N.J., I980), I70; Xavier de Planhol and Paul Claval, An Historical Geography of France (New York, I994), 26I-266, 245, 346-354; Ministère des Travaux Public, Album de Statistique Graphique de 1886 (Paris, I887), map 28 ("Poids des animaux de l'espèce bovine par hectare du territoire total en I 882 ”). 
scribed the much expanded wine industry as "the foundation for unparalleled wealth. . . . There is perhaps no other region in Europe for which the railway had occasioned more affluence and prosperity than in the Department of the old Languedoc." 22

THE AGRARIAN DEPRESSION, C. I876 TO I896 As international transport costs fell, vast amounts of cheaper grain-especially wheat-from the American heartland landed in European markets, joined eventually by growing quantities from Canada, Australia, and Russia. Accordingly, prices fell lower and lower. Farmers who had managed to adjust to intensifying domestic competition now faced the greater challenge of relentless competition from abroad. As mentioned above, in response to falling prices for cereals and steady or rising prices for fresh meat, French farmers in the Allier, northern Burgundy, and Normandy, and English farmers in Wiltshire, Dorset, and Derbyshire-to name a few prominent examples - increasingly shifted to stock raising or dairy farming, converting arable fields into pasture, and lowering their wage bill since cattle farming and dairying required fewer hands than cereal farming. ${ }^{23}$

In response to the crisis and pressure from agrarian interests, the governments of Britain and France adopted different policies. In Britain, the government held fast to free trade, leaving landlords and farmers to handle market conditions and international compe-

\footnotetext{
22 Caron, Histoire des chemins de fer, 569.
}

23 British Parliamentary Papers, Royal Commission on Agriculture, Final Report of Her Majesty's Commissioners appointed to enquire into the subject of Agricultural Depression, I 897, 56. For a useful overview of British policy and the depression, see Avner Offer, The First World War, an Agrarian Interpretation (New York, I989). Kevin H. O’Rourke and Jeffrey G. Williamson,"When Did Globalization Begin?" European Review of Economic History, VI (2002), 23-50; idem, "Once More: When Did Globalization Begin?” ibid., VIII (2004), I09I I7; White, "It's Your Misfortune and None of My Own," 242-246; Liebowitz, "Tenants," 43844I. Accounts vary as to the timing, extent, and consequences of the agrarian crisis in France. Toutain, "La croissance inégales," 352, tempers the grave assessment offered in Maurice LévyLeboyer and François Bourguigon, L'économie française au XIXe siècle: analyse macro-économique (Paris; I985). Hohenberg, "Change in Rural France," and Liebowitz, "Tenants," concur in seeing a crisis of real but limited effects. Comparisons of regional patterns in the French Departments of the Allier and Côte-d'Or with the English County of Dorset are presented in Schwartz, "Rail Transport and the Agrarian Crisis"; idem and Thomas Thévenin, "Railways and Agriculture in Britain and France, I850-I9I4, in Alistair Geddes and Gregory (eds.), Rethinking Space and Place: New Directions in Historical GIS (Bloomington, forthcoming). For Wales, see Schwartz, Gregory, and Marti-Henneberg, "History and GIS: Railways, Population Change, and Agricultural Development in Late Nineteenth Century Wales" (Washington, D.C., forthcoming). 
tition as best they could. In France, a long history of state intervention prevailed in the form of protective tariffs and a vast program of railway expansion. ${ }^{24}$

RAIL SERVICE AND NET MIGRATION IN ENGLAND AND WALES Although agrarian distress tended to accelerate rural depopulation, the rate of rural depopulation was apt to differ depending upon regional and local conditions in agriculture and the proximity of alternative employment in towns. Hence, the gains and losses due to net migration from the I860s to the I890s varied considerably across England and Wales (see Figure Io). In rural areas, the highest levels of out-migration were located in the agrarian zones of southern England and central Wales. The affected districts lay within a band running from the tip of Cornwall in the southwest to East Anglia and Lincolnshire in the east, Central Wales and Gloucestershire forming an isthmus. Generally, out-migration in these areas peaked during the I870s and then subsided in the following decade. Notable exceptions to this trend, however, were central Wales and scattered clusters in East Anglia and Lincolnshire, where high rates of out-migration continued into the I 880 os.

To the extent that rail service bolstered the economies of rural communities, accessible service was apt to stem migration from rural areas. In other words, railway accessibility and out-migration ("negative net migration") have a positive relationship — as railway accessibility increases, out-migration (negative values) tends to diminish. Geographically weighted regression (GWR) can be used to test this proposition. ${ }^{25}$

GWR is an extension of ordinary least-squares linear regression (ols). Like ols, the method enables a description of a straight-line relationship between a dependent variable, such as net migration,

24 In his comparative study, Forging Industrial Policy, Frank Dobbin makes a strong case for this contrast with respect to British and French railway policy but does not pursue the question of actual implementation. Investigating the results of implementation at national, regional, and local scales is the primary object of our research. See our articles in note 23 , and Schwartz, "Rail Transport and the Agrarian Crisis."

25 This analysis was carried out with GWR 3, a copyrighted program by Martin Charlton, Stewart Fotheringham, and Chris Brundson, Department of Geography, University of Newcastle. See their Geographically Weighted Regression: The Analysis of Spatially Varying Relationships (Chichester, 2002). To obtain a license, email stewart.fotheringham@nuim.ie. Bandwidth is the number of contiguous aerial units ("nearest neighbors") used to calculate the local regression estimates. The area units in this analysis are census registration districts. The GWR program uses an iterative algorithm to determine the optimal number of units or cases. 
Fig. 10 Population Change due to Net Migration in England and Wales, I 86 I-I 89 I
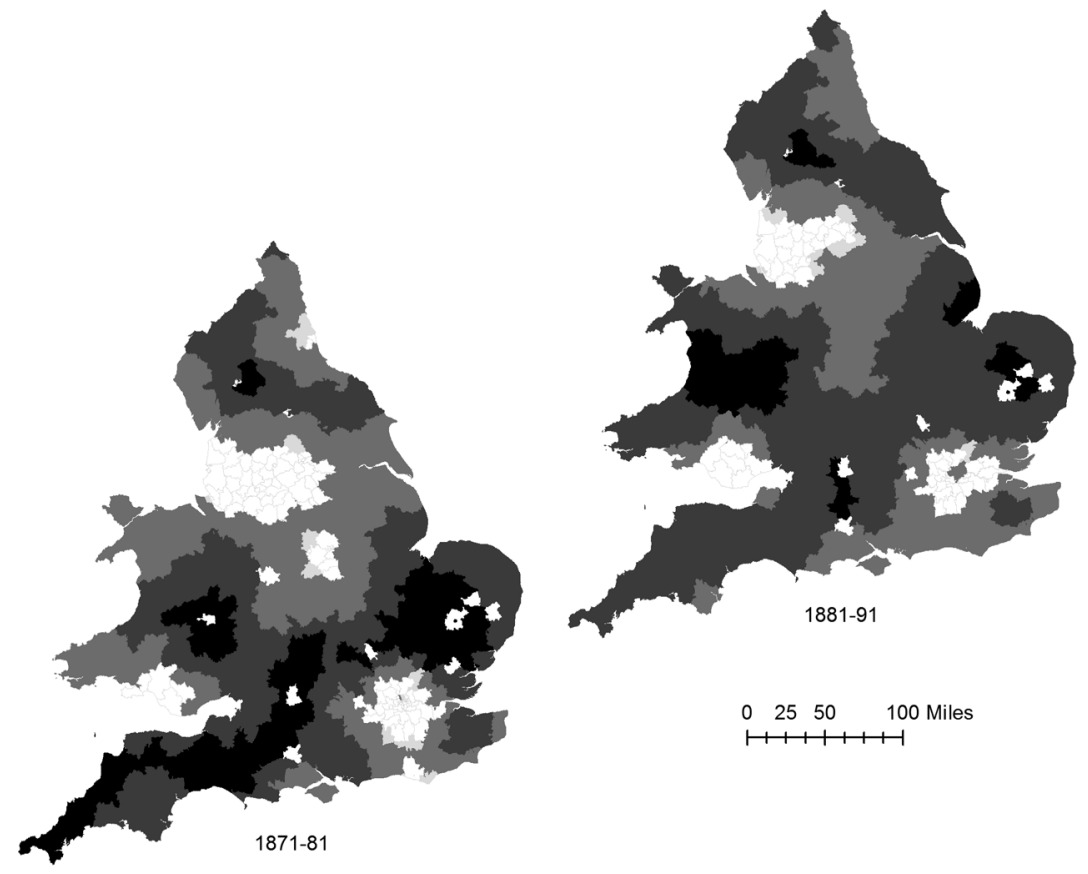

Mean Net Migration

Percent Change
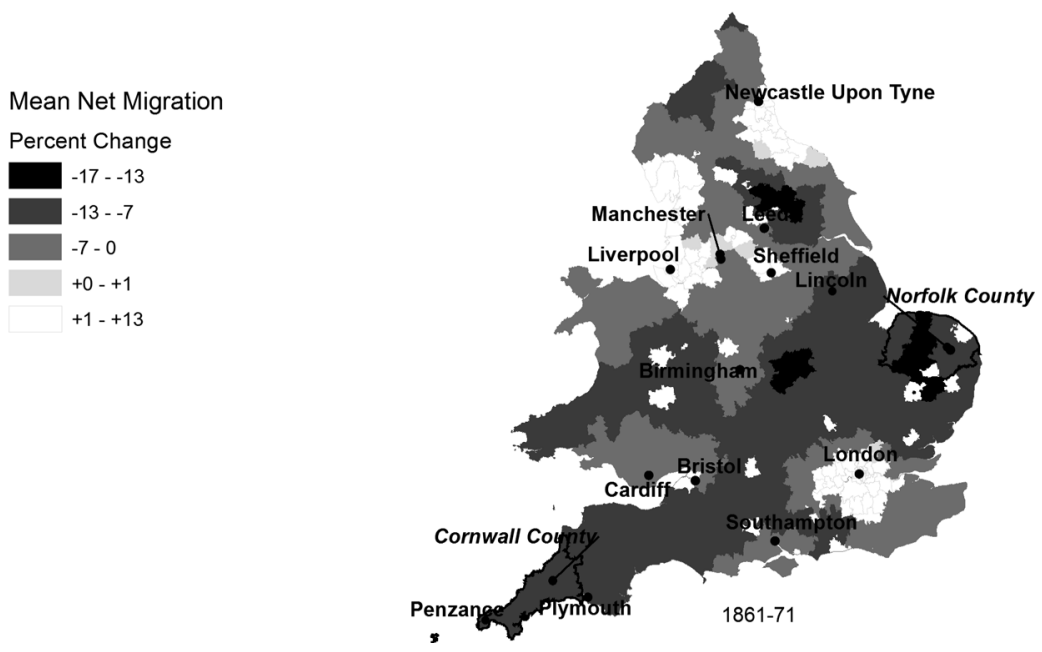

SOURCE Humphrey Southall and Gregory, Great Britain Historical GIS, information at http://www.gbhgis.org/; Gregory, Chris Bennett, Vicki L Gilham, and Southall, "The Great Britain Historical GIS Project: From Maps to Changing Human Geography," Cartographic Journal, XXXIX (2002), 37-49. 
Table 1 GwR Results

\begin{tabular}{llcc}
\hline PERIOD & $\begin{array}{l}\text { STATISTICAL SIGNIFICANCE OF } \\
\text { RAIL DENSITY }(\mathrm{P}<=.05)\end{array}$ & $\begin{array}{c}\text { R-SQUARE STATISTIC } \\
\text { FOR THE REGRESSION }\end{array}$ & $\begin{array}{c}\text { NO. OF } \\
\text { DistriCTS }\end{array}$ \\
\hline I86I-7I & Not significant & .24 & 595 \\
I87I-8I & Significant & .42 & 606 \\
I88I-9I & Significant & .39 & $6 \mathrm{I} 6$ \\
\hline
\end{tabular}

NOTE Percentage population change due to net migration $=$ density of rail lines $(\mathrm{km}$ of rail per square $\mathrm{km}$ of district area) + rurality (distance to the closest city with 300 or more persons per square $\mathrm{km}$ ) + the ruggedness of terrain (standard deviation of a district's mean elevation) (see also Table A2 in the Appendix).

and one or more independent or explanatory variables. But whereas OLS produces an estimate of the linear relationship of the variables over the whole study area, GWR produces a set of best estimates, each estimate being the result for a specific group of contiguous spatial units within the whole study area. Instead of one result that is an average estimate for the study area, it provides estimates for each of a number of spatial units. In short, GWR brings out the geographical variation in the relationship between the dependent and explanatory variables. The specific example of net migration helps to make this point clear.

The proposition under study posits that variations in net migration result, in part, from the interactive effect of three variables: (I) rail density (an indicator of accessible service), (2) distance from an urban population center, and (3) the relative ruggedness of the terrain. Data for three decades-I86I-I87I, I87I-I88I, and I $88 \mathrm{I}-\mathrm{I} 89 \mathrm{I}$ - can be used to test it, seeing that that the purported relationship may well vary over time as well as geography. The lack of a statistically significant fit for the I86I-I87I decade, together with the statistically significant fit for the two following decades, suggests that the influence of rail transport on migration took hold ten years after rail lines first began to reach the majority of rural districts. The results for the I 870 s and I 88 os suggest that rates of rural out-migration during those decades were reduced in rural districts where higher levels of rail transport were available (see Table I). The best way to grasp this relationship is to map the geographically varying influence of rail density on net migration (see Figure I I).

As displayed in Figure Io, the positive relationship between rail transport and net migration appears to have been greatest in 
Fig. 11 The Effect of Rail Density on Net Migration in England and Wales, I 87 I-I $88 \mathrm{I}$

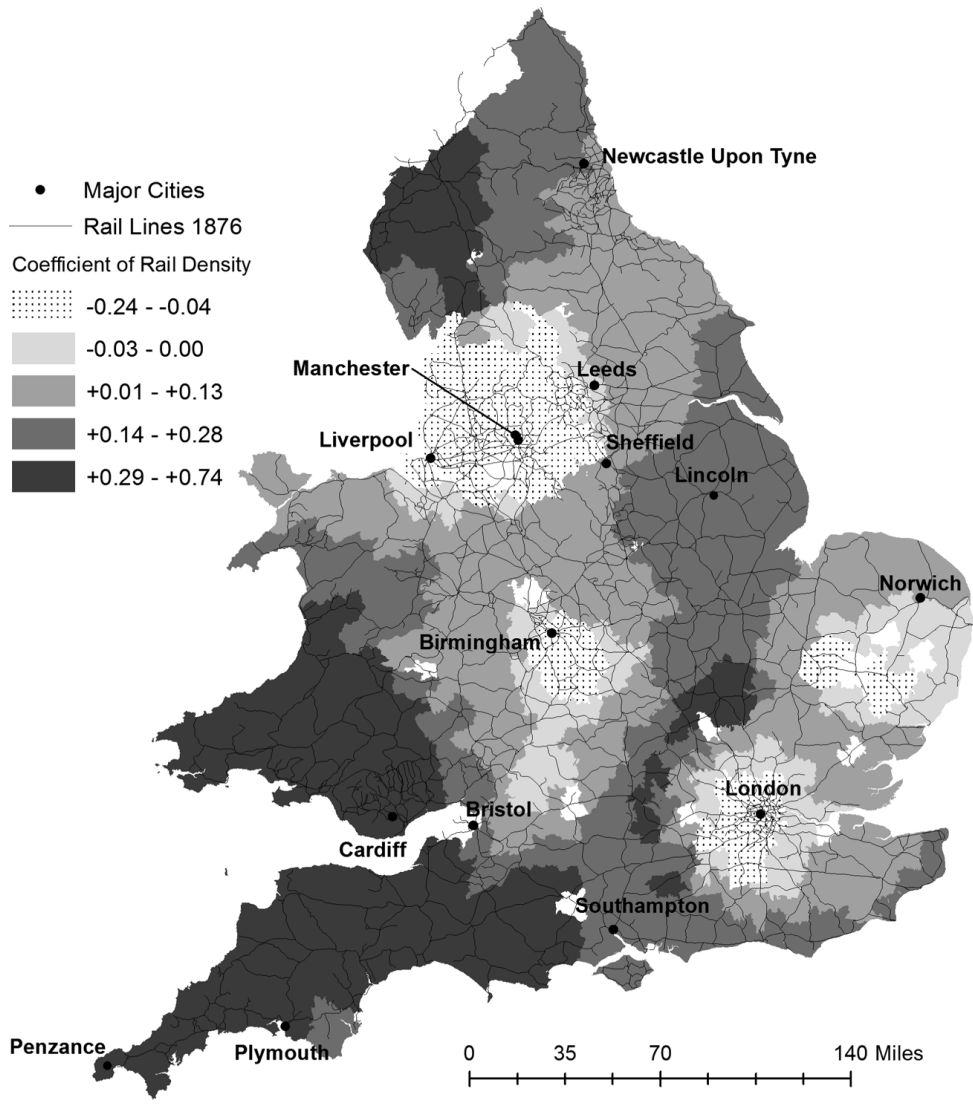

the areas shaded in dark blue-the rural districts from Bristol to Penzance in the southwest, those in a band to the north and west of London, those in the far northwest, and those in a Welsh triangle covering parts of the central region and all of the south. In sum, during the 1870 s (and I880s), in rural regions that were already losing population, rail transport tended to diminish the rate of rural depopulation to a degree that varied geographically, greater in parts of central and southern Wales, the southwest, and the far northwest. Given the agrarian depression during these decades, the commercial benefits of accessible rail service in rural 
communities arguably reduced the pace of rural depopulation to a greater or lesser degree.

RAIL SERVICE AND POPUlation CHANGe IN FRANCE For France, where data on net migration is unavailable, a comparable analysis can be undertaken by estimating the effect of rail service on population change from I86I to I892. As in Britain, the effects of rugged topography and distance from a center of urban population are combined with measures of accessible rail service. But for France, rail service is measured by two variables - the density of rail stations in a canton, the equivalent of a British registration districtand the shortest distance from the center of a rural canton to an urban canton with a population density of more than $\mathrm{I} 2 \mathrm{O}$ persons per square $\mathrm{km}$.

Figure 12 shows that high rates of depopulation $(-32$ to - I3 percent) were clustered in the peripheries of the country: Normandy; mountainous and upland regions in the south, southeast, and the Ardennes, the Aube, Côte d'Or, Haute-Saône, and the Jura; and in inland cantons northeast of Bordeaux (the Charente). Modest to high levels of population increase occurred in the center, in the coastal and inland cantons of southern Brittany, the Bordeaux area, and the Mediterranean basin; in uplands of the Vosges; in the industrial areas in the Northeast (the Pas-de-Calais and the Nord), and in the Paris agglomeration.

The GWR analysis captures important aspects of this geography of widely varying population loss and increase. Overall, it accounts for about 40 percent of the variation in population change. More specifically, it attests to the differing spatial relationships between demographic change, rail accessibility, terrain, and rurality - that is, remoteness from urban areas (see Table A2 in the Appendix.) Mapping the local $\mathrm{R}^{2}$ values (a measure of the model's goodness of fit) shows that the statistical fit between the hypothesis and the actual data varies from poor to moderately good, depending upon region. It was poor in Normandy, the Pyrenees, Languedoc, the Alps, and the southern Jura and relatively good in the northeast (including Paris), Brittany, the West and Southwest, the Lyon area, parts of Burgundy, and the Vosges (see Figure I3).

As for the effect of rail accessibility, the positive values of the parameter estimates for station distance and station density suggest that the positive effects worked in one of three ways across the af- 
Fig. 12 Percentage of Population Change in French Cantons, I86II 892

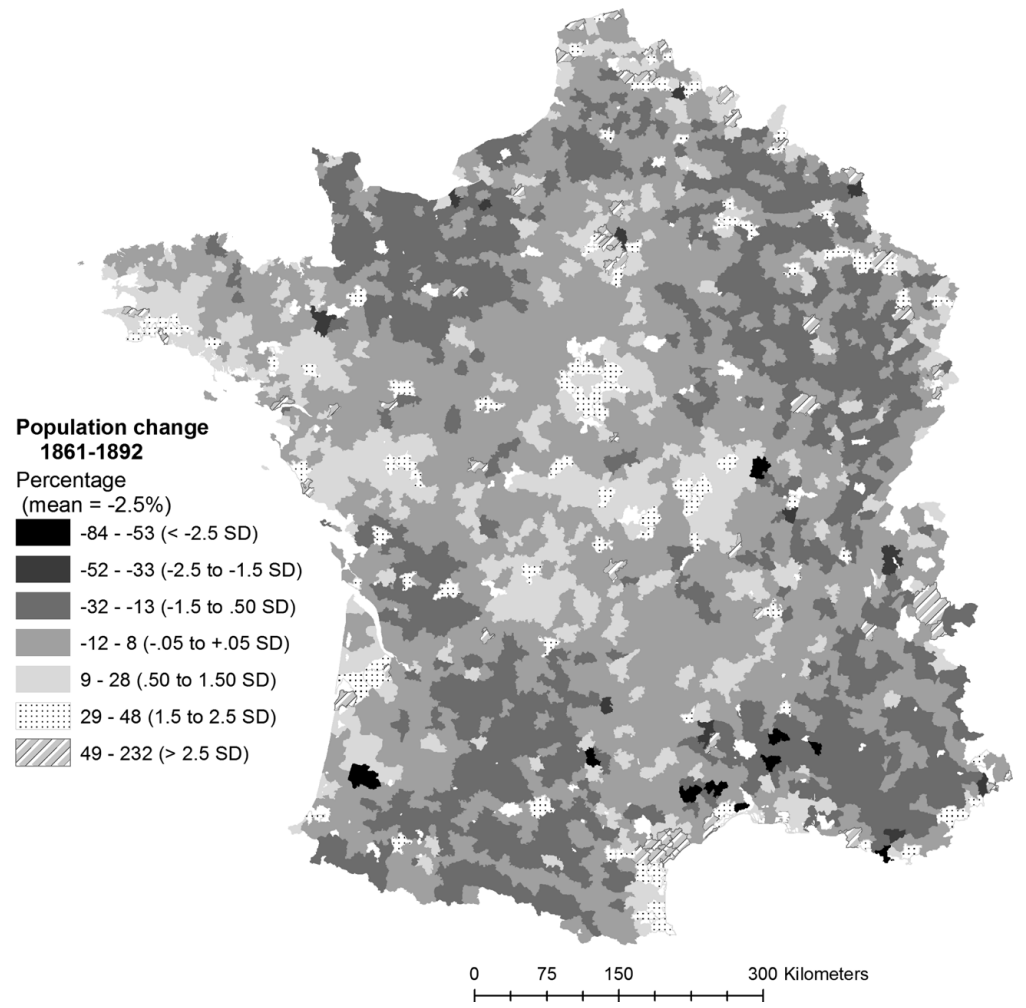

fected cantons and regions between I86I and I892. Accessibility worked either to reduce the pace of depopulation, to stabilize population change, or to foster some degree of population growth. Significantly, these cantons and regions were mainly clustered in the traditionally less-developed west and south below the Saint Mâlo-Geneva line (see Figure I4). The same patterns of demographic change-depopulation, stability, and growth-took place in the cantons and regions of the north. Not surprisingly, population growth was strong in the Paris region and the agroindustrial areas of the northeast. But there, where rail service had long been dense and concentrated, rail accessibility evidently played a neutral or negative role in population changes between I 86I and I 892. From the perspective of Massey's contingent paths of spatial development, by the I890s railway expansion and in- 
Fig. 13 Percentage of Population Change in France, I86I-I 892: Distribution of Local $\mathrm{R}^{2}$ Values from a GWR Regression on Station Density, Distance to Closest Station, Distance to Urban Canton with Population Density of I2O Inhabitants per Square Kilometer or More, and Ruggedness of Terrain (Standard Deviation of Mean Cantonal Elevation)

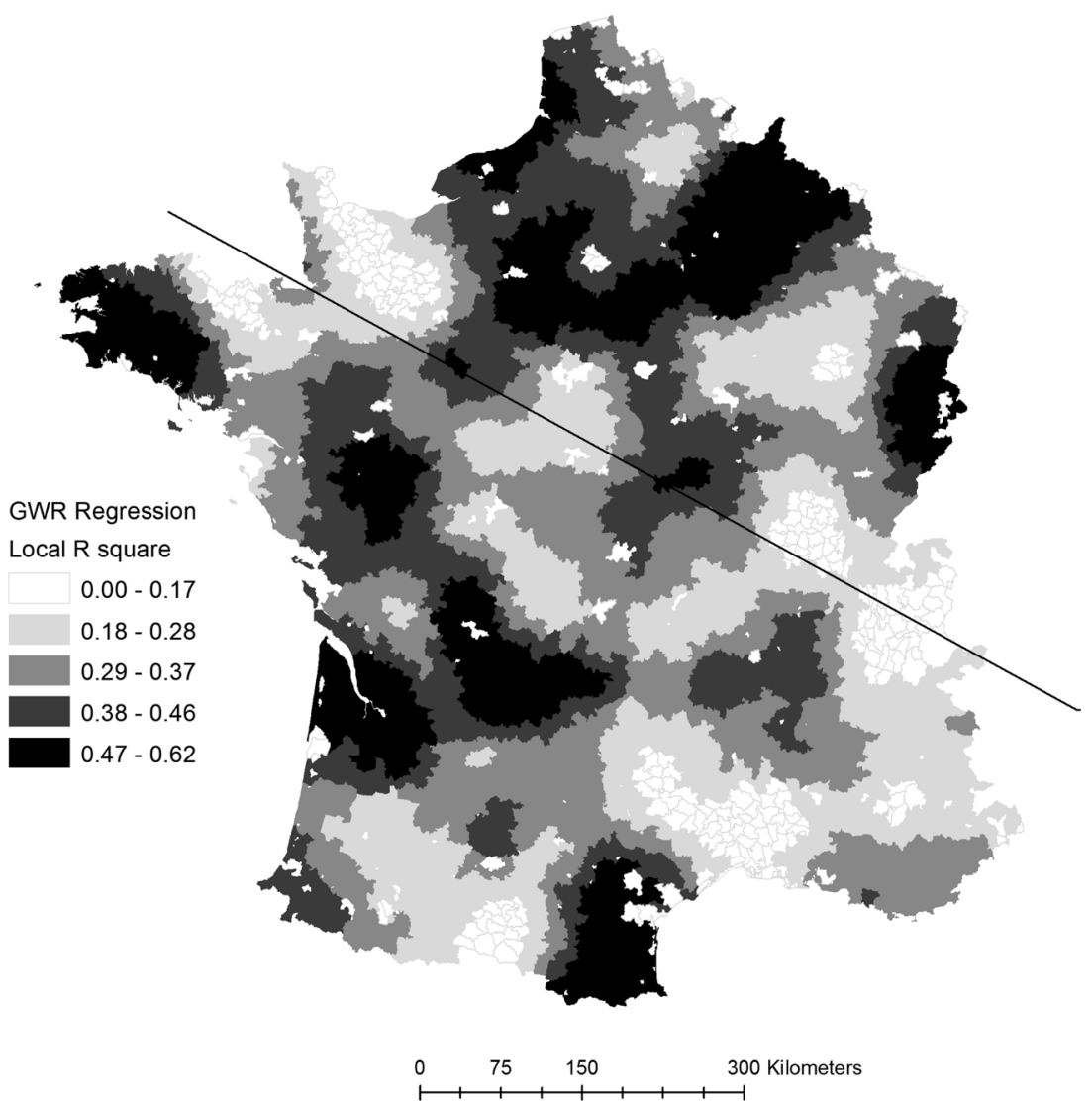

creased accessibility to rail transport in the west and south of France was helping to bring about a material restructuring of space and place in areas considered less developed. The Third Republic's effort to make modernizing rail service more accessible to those traditionally disadvantaged regions was bringing results.

The benefits - and costs — of the railway age clearly affected the lived experiences of people in French and British rural communi- 
Fig. 14 The Effect of Railway Accessibility on Percentage of Population Change, I86I-I892: Distribution of Regression Coefficients of the Variables Distance to Closest Rail Station in Kilometers, and Rail-Station Density in Cantons (Both from the GWR Regression Described Above)

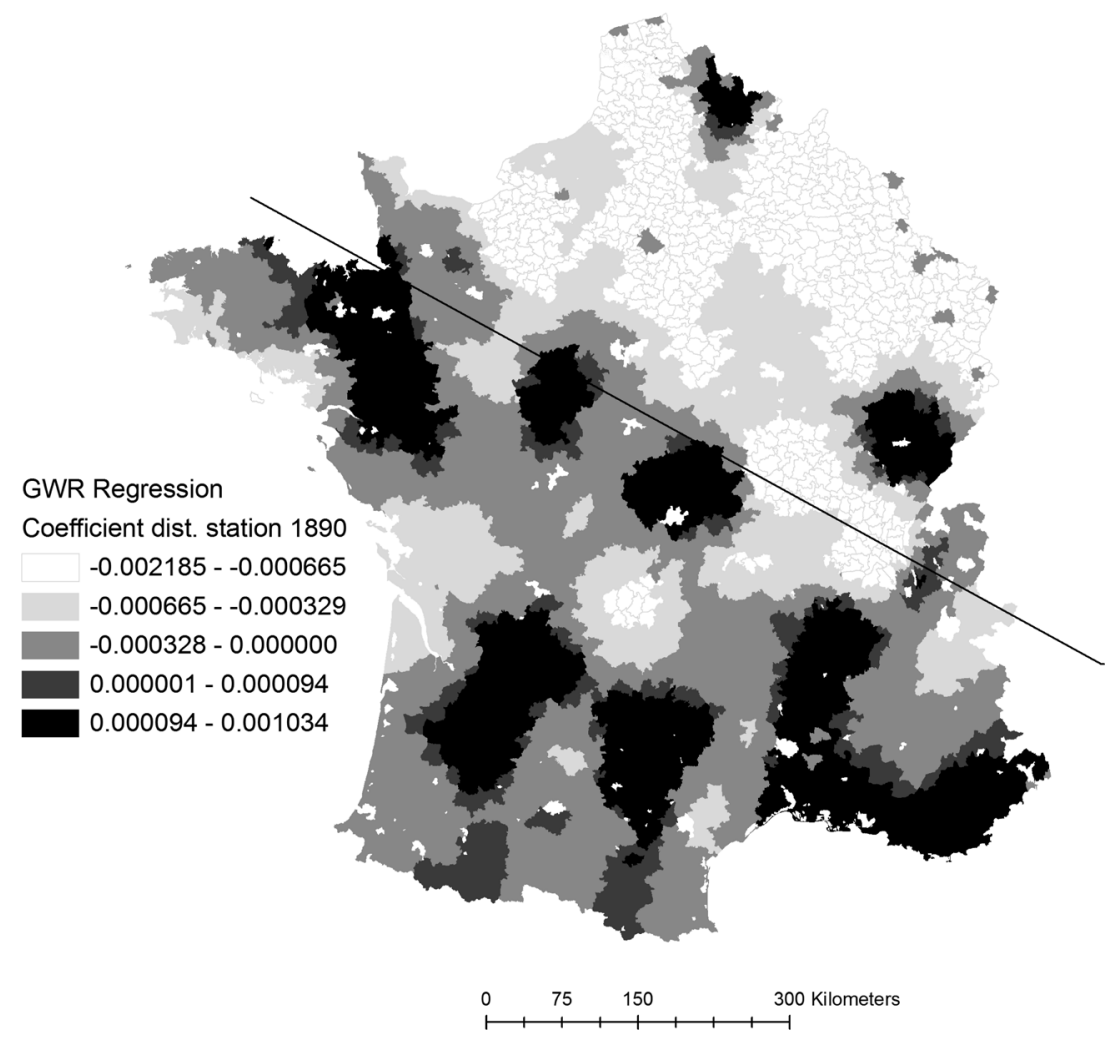

ties. Communities with little or no access to rail transport were likely to pass through stages of stagnation, depopulation, and decline to a greater degree than communities favored by a railway station within a half-day's walk. In agrarian villages thus favored, improved capacities for marketing local foodstuffs to meet growing demand in cities stimulated production, especially in livestock and such perishables as fresh milk and butter, vegetables, and fruits. Meanwhile, as employment in the contracting sector of cereal farming declined, new jobs in carting, logging, blacksmithing, or 
Fig. 14 (Continued)

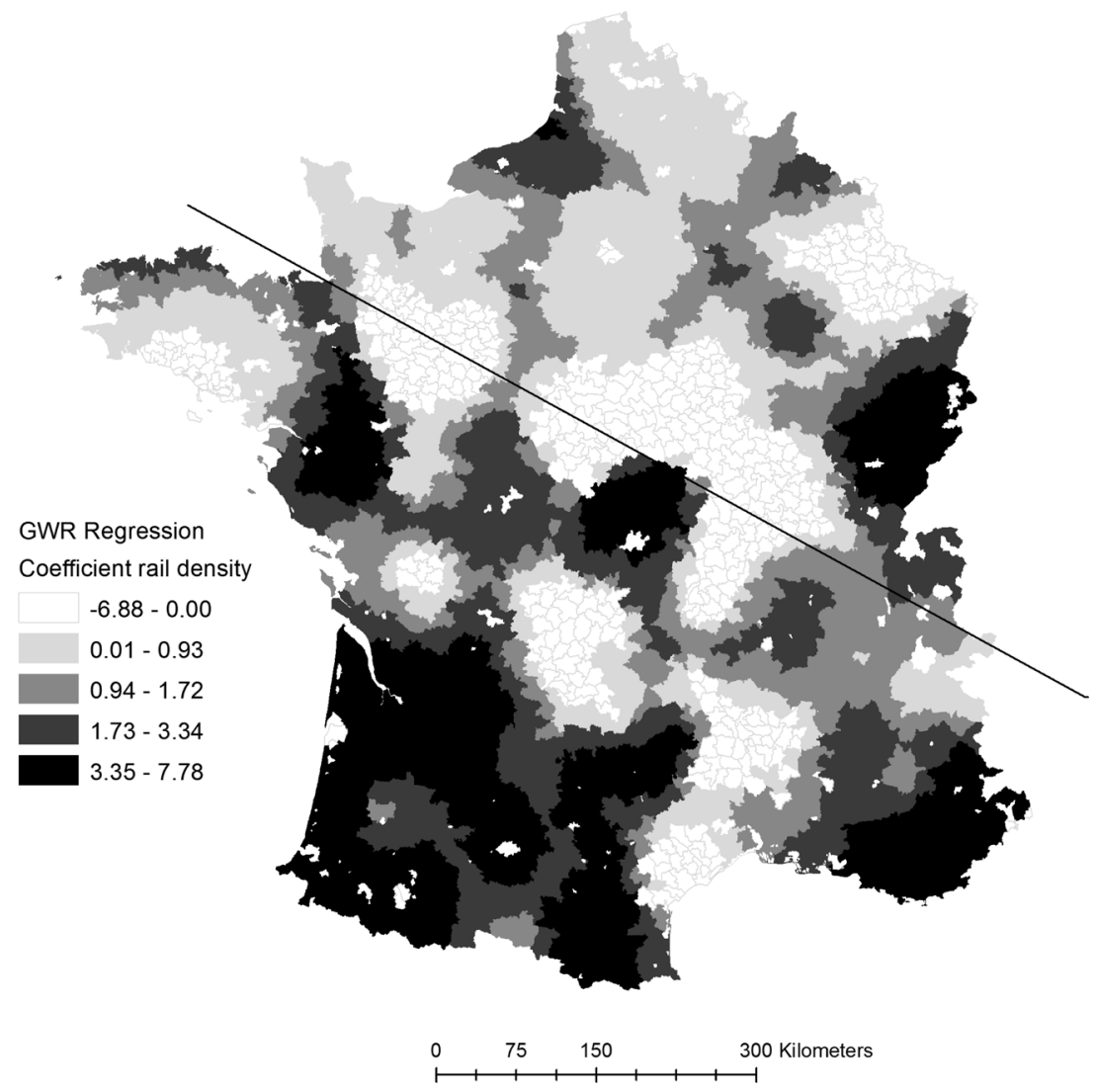

SOURCES France Railway GIS; the French census of I89I, published in the Bulletin des Lois de la République Française, No. I474 (Paris, I892), 884-924; digital terrain model constructed by Schwartz from the Shuttle Radar Mission images, distributed by the United States Geological Survey; France Railway GIS, rail lines digitized from Carte des chemins de fer française: SNCF, 1944, Département des Cartes et Plans, Ge BB 368, Bibliothèque National de France, Paris.

other artisanal and service trades helped to stem out-migration, as did mining in rural areas where coal or other minerals could be more fully exploited once rail service were established. Although railways and the attending transport revolution engendered intensified domestic and international competition, farmers benefiting 
from proximate rail service had better options than those who did not to adjust to new market conditions.

In these and other ways, a spatial history of rail transport and its effects in rural Britain and France offers new comparative understandings of geographical and temporal change in agriculture and population from the I 850 os to the eve of World War I. The ability of GIS to join a wide range of data by means of spatial location enlarges the scope of comparative historical investigation, making possible the study of change at different scales of spatial resolution-international, national, regional, and local. The growth of rail transport in the countryside, the impact of the globalizing wheat trade, the shift from cereals to livestock and dairy farming, the expanding production of perishable fruit and vegetables for distant markets, the gain and loss of employment in agriculture, extractive industries, carting, and other services all need to be understood as interrelated changes moving through global to local levels of activity, reaching even small farms and influencing people's decisions about marriage and celibacy, family size, and outmigration. At the national and regional levels, the arrival of rail transport in the countryside brought economic benefits that slowed the so-called rural exodus in parts of Britain and France. Elsewhere, we are exploring more closely regional and local connections between railway expansion and agriculture development, as well as the influence of rail transport on rural cultural change through the increased circulation of newspapers and expanded postal service.

These discoveries assist further explorations in the cultural territory of spatial history. In both Britain and France, for example, political and social concerns about "the rural exodus" can now be re-examined against new and more precise patterns of rural depopulation, the better to disentangle moderate demographic change from the cultural anxiety that the virtues of hard work and sacrifice rooted in villages would decline or disappear as the increasing flow of rural migrants emptied the countryside. Mapping the increased circulation of newspapers and mail provides a context for studying news items, adverts, tool catalogues, posters, railway timetables, and letters from loved ones-all communications from afar-and teasing out clues therein about changes in villagers' imagined geography of distant places (capital cities, the seaside, 
the nearest town, and sites of job prospects a long way from home). In sum, this article illustrates the promise of spatial history, a promise that requires no previous training in GIS or spatial statistics to appreciate. Neither Bloch nor Braudel knew anything about these methods, but they would have welcomed the undertaking and the results. ${ }^{26}$

\section{APPENDIX: SUPPLEMENTARY TABLES}

Table A1 Geographically Weighted Regression (GWR)-Britain, I87I-I88I

\begin{tabular}{lcc}
\hline & TYPE OF MULTIPLE REGRESSION ANALYSIS \\
\cline { 2 - 3 } & ORDINARY LEAST SQUARES & GEOGRAPHICALLY WEIGHTED \\
\hline Cases fit $(\mathrm{N})$ & 606 & 606 \\
Adjusted r-square &. $\mathrm{I} 9$ & .42 \\
Parameters & & P-values \\
Intercept & & .00 \\
Rail density & & .05 \\
Rurality & & .00 \\
Terrain ruggedness & & .00
\end{tabular}

PARAMETERS: FIVE NUMBER SUMMARIES OF REGRESSION COEFFICIENTS

\begin{tabular}{lcccrr}
\hline & & & & UOWER \\
PARAMETER & MINIMUM & QUARTILE & MEDIAN & QUARTILE & MAXIMUM \\
\hline Intercept & -20.821535 & - I0.385050 & -5.492135 & I.I6III6 & I9.240993 \\
Rail & -0.229497 & 0.010774 & 0.090363 & 0.230244 & 0.659132 \\
$\quad$ density & & & & & \\
Rurality & -0.000984 & -0.000358 & -0.000240 & 0.000 II9 & 0.000057 \\
Terrain & -0.283285 & -0.040649 & 0.002422 & 0.075573 & 0.553146 \\
$\quad$ ruggedness & & & & & \\
\hline
\end{tabular}

NOTE Percentage population change due to net migration in $\mathrm{I} 87 \mathrm{I}-\mathrm{I} 88 \mathrm{I}=$ rail density in I 876 (rail lines per square $\mathrm{km}$ of registration district area) + rurality (distance to the closest

26 For more information about regional and local connections between railway expansion and agriculture development, as well as the influence of rail transport on rural cultural change through the increased circulation of newspapers and expanded postal service, see Schwartz, "Rail Transport and the Agrarian Crisis"; idem and Thévenin, "Railways and Agriculture"; Schwartz, Gregory, and Martí-Henneberg, "History and GIS." Pre-publication versions of our papers and presentations can be found at our website-www.mtholyoke.edu/courses/ rschwart/railways. 


\section{Table A1 (Continued)}

urban district with 300 persons per square $\mathrm{km}$ or greater in $\mathrm{I} 880$ in meters) + ruggedness of terrain (standard deviation of mean terrain elevation in meters).

Unlike ordinary OLS, GWR fits not one but a number of regression lines to the data, each line being the best linear fit for a spatial cluster of cases in the study area. To calculate the GWR results, a moving window proceeds across the study area, using an algorithm to determine the units that comprise each cluster case to which a best-fitting regression line is fitted. The general aim of GWR is twofold - to determine whether there are spatially varying relationships of statistical significance among the specified variables for the study area and, when such relationships exist, to provide a measure of the total variance explained by the independent variables $\left(\mathrm{R}^{2}\right)$ and estimates of the coefficients for each term in the regression equation. The comparison between OLS and GWR results provides a good indication of the presence or absence of spatial dependence - that is, spatially varying relationships. The five-number summaries provide a range of the coefficient estimates. For study and interpretation, the mapping of GWR results complements the numerical summaries by offering a visual means of identifying spatial patterns.

Table A2 GWR: France, Railways, and Population Change, I86I-I 892

TYPE OF MULTIPLE REGRESSION ANALYSIS

\begin{tabular}{lcr}
\cline { 2 - 3 } & $\begin{array}{c}\text { ORDINARY LEAST } \\
\text { SQUARES }\end{array}$ & $\begin{array}{c}\text { GEOGRAPHICALLY } \\
\text { WEIGHTED }\end{array}$ \\
\hline Cases to fit $(\mathrm{N})$ & 2,500 & 2,500 \\
Adjusted $\mathrm{R}^{2}$ & .07 & $.4 \mathrm{I}$ \\
Parameters & & P-values \\
Intercept & .00 \\
Station density & $.0 \mathrm{I}$ \\
Closest station distance & .00 \\
Rurality & .00 \\
Terrain ruggedness & .00 \\
\hline
\end{tabular}

PARAMETERS: FIVE NUMBER SUMMARIES OF REGRESSION COEFFICIENTS

\begin{tabular}{|c|c|c|c|c|c|}
\hline PARAMETER & MINIMUM & $\begin{array}{c}\text { LOWER } \\
\text { QUARTILE }\end{array}$ & MEDIAN & $\begin{array}{c}\text { UPPER } \\
\text { QUARTILE }\end{array}$ & MAXIMUM \\
\hline Intercept & 24.7 I 3 I I 5 & I0.336263 & $3 \cdot 383647$ & 5.IOI 888 & $27.80537 \mathrm{I}$ \\
\hline $\begin{array}{l}\text { Station } \\
\text { density }\end{array}$ & 6.876633 & 0.485668 & I.388862 & 2.925010 & 7.7797 I 7 \\
\hline $\begin{array}{l}\text { Closest station } \\
\text { (in meters) }\end{array}$ & -0.000049 & -0.0000 I I & -0.000005 & 0.000004 & 0.000035 \\
\hline Rurality & 0.002185 & 0.000573 & 0.00022 I & 0.000026 & 0.001034 \\
\hline $\begin{array}{l}\text { Terrain } \\
\text { ruggedness }\end{array}$ & -0.010577 & -0.001694 & -0.000219 & 0.001032 & O.OIIOI9 \\
\hline
\end{tabular}

NOTE Population change, I861 to I892 $=$ rail station density (number of stations per square $\mathrm{km}$ of cantonal area) + closest station distance + rurality (distance to the closest urban canton with population density greater than I2O persons per square $\mathrm{km}$ ) + ruggedness of terrain (standard deviation of the mean elevation of a canton). 